\title{
NEW SPECIES OF FICUS (MORACEAE) FROM SOUTH AMERICA
}

\author{
C.C. BERG \\ Bergen Museum, University of Bergen, Allégate 41, 5007 Bergen, Norway; \\ Nationaal Herbarium Nederland, Universiteit Leiden branch, P.O. Box 9514, \\ 2300 RA Leiden, The Netherlands; berg@nhn.leidenuniv.nl
}

\section{SUMMARY}

Eleven new species and one new subspecies of Ficus from South America, mainly from the Andean region, are described and illustrated: F. cotopaxiensis, F. ecuadorensis, F. francoae, F. jacobii subsp. mantana, F. loxensis, F. maximoides, F. pastasana, F. quichuana, F. quistocochensis, F. rimacana, $F$. sumacoana, and F. valaria. Ficus malacocarpa Standl. is reduced to a subspecies of $F$. popenoei Standl.

Key words: Moraceae, Ficus, South America.

\section{INTRODUCTION}

Continuation of studies on Ficus in tropical America is currently focussed on the preparation of a treatment of the genus for the Flora of Ecuador. It is one of the last steps in the preparation of a monograph of the neotropical representatives of the genus. New species and subspecies have been discovered and are published here. This study supplements similar studies of other parts of the Neotropics, as Vázquez Avila et al. (1986), Berg \& Franco (1996), Berg \& Carauta (2003), and Berg \& Villavicencio (2003).

Most of the new taxa belong to subg. Urostigma (Gasp.) Miq. sect. Americanae Miq., a group of (potentially) hemi-epiphytes. Three of the new species, F. ecuadorensis, F. loxensis, and F. maximoides, belong to sect. Pharmacosycea (Miq.) Miq. sect. Pharmacosycea (Miq.) Benth. \& Hook.f. subsect. Petensenses Carvajal \& Shabes (see Berg, 2006), a group of terrestrial trees.

\section{Ficus cotopaxiensis C.C. Berg., spec. nov. - Fig. 1}

Fico hartwegii similis, venis lateralibus plus numerosis, indumento e pilis longitudinibus dissimilibus quoque in paginae inferioris venis minoribus differt. - Typus: Berg 1275 (holo QCA; iso A, AAU, BG, COL, GB, K, LOJA, MO, NY, QCNE, U, US), Ecuador, Cotopaxi, road Quevedo-Latacunga, between El Tingo and Guyacal, c. 1100 m, 17 Feb. 1981.

Tree to 20(-30) $\mathrm{m}$ tall. Leafy twigs $2.5-4 \mathrm{~mm}$ thick, densely minutely whitish to brownish puberulous, the short hairs intermixed with distinctly longer, brown to whitish, crinkled to straight ones; periderm flaking off in small flakes. Lamina (sub) coriaceous, oblong to subobovate to elliptic or to lanceolate, (5-)10-20 by (2.5-)4-7.5 cm, apex acuminate, base rounded to subcordate or to cuneate, margin entire; upper surface 


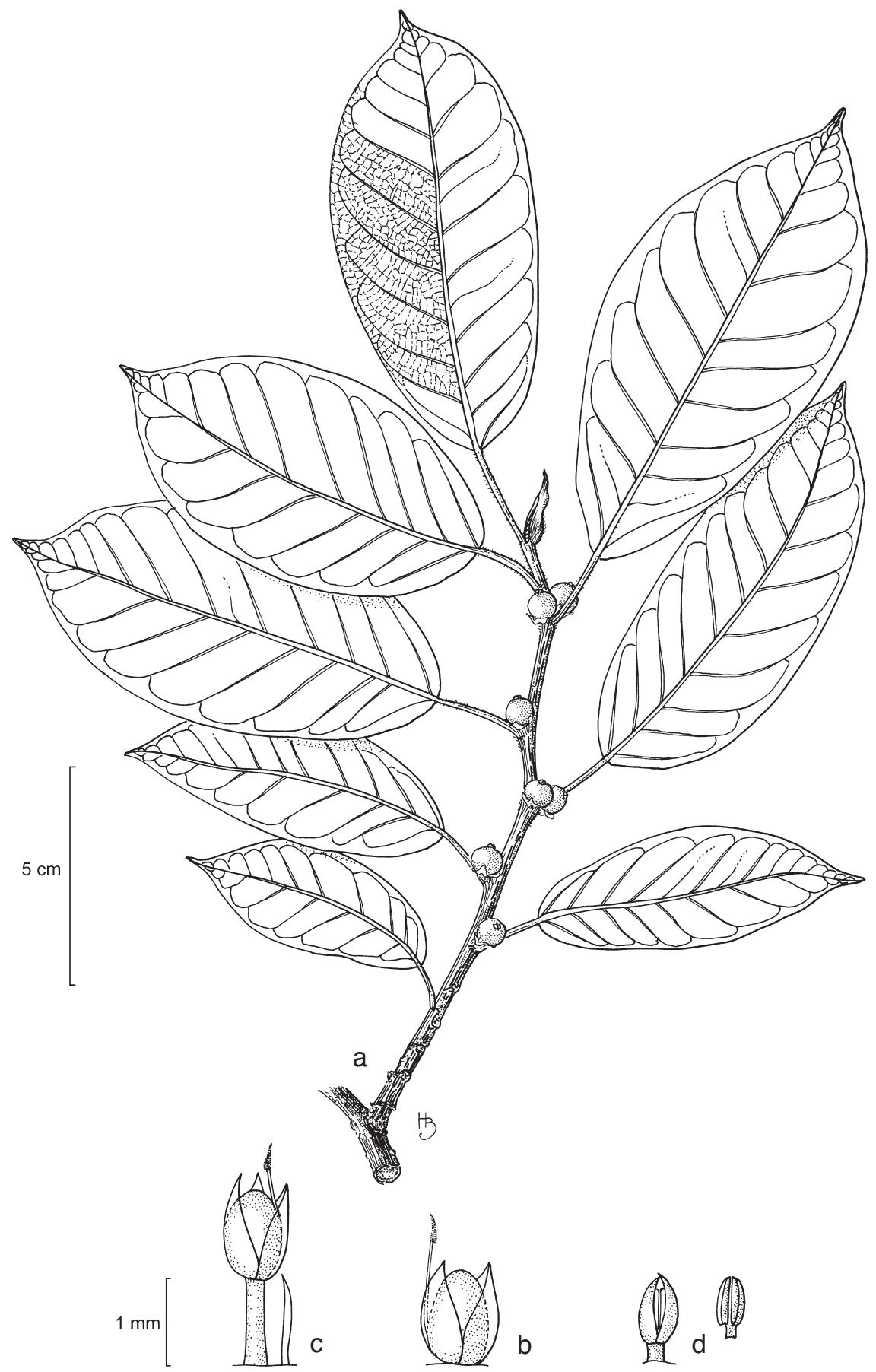

Fig. 1. Ficus cotopaxiensis C.C. Berg. a. Leafy twig with figs; b. long-styled pistillate flower; c. shortstyled pistillate flower and interfloral bract; d. staminate flower and stamen (all: Berg 1275, BG). 
sparsely minutely whitish to brownish puberulous on the midrib to glabrous, smooth, lower surface whitish to brownish puberulous to tomentose on the veins, on the midrib or also on the lateral veins the short hairs intermixed with distinctly longer, brown to whitish, crinkled to straight, \pm patent to appressed ones; lateral veins (6-) $10-12(-14)$ pairs, the basal pair up to $1 / 10-1 / 5$ the length of the lamina, unbranched, tertiary venation reticulate; petiole $1-4(-7) \mathrm{cm}$ long, densely minutely whitish to brownish puberulous, the short hairs intermixed with distinctly longer, brown to whitish, crinkled to straight ones, the epidermis flaking off in small flakes; stipules $0.3-1$ (on flush up to 2.5) $\mathrm{cm}$ long, minutely whitish to brownish puberulous and brown to whitish strigose to subhirtellous outside, glabrous inside, caducous. Figs axillary, in pairs or solitary, sessile; basal bracts 2, c. $3 \mathrm{~mm}$ long, pilose outside, glabrous inside; receptacle subglobose, $0.5-0.7 \mathrm{~cm}$ diam. when dry, pilose, ostiole c. $2.5 \mathrm{~mm}$ diam., slightly prominent; closed by 3 bracts; internal hairs absent. Staminate flowers $0.2-0.4$ $\mathrm{mm}$ long pedicellate; tepals 3, 0.6-0.8 mm long; stamen 1. Pistillate flowers: tepals ( 2 or) 3, 0.8 $-1.2 \mathrm{~mm}$ long; stigma c. $0.3 \mathrm{~mm}$ long; long-styled flowers sessile; style $0.8-1.2 \mathrm{~mm}$ long; short-styled flowers to $1 \mathrm{~mm}$ long pedicellate; style $0.4-0.6 \mathrm{~mm}$ long. Interfloral bracts few, c. $1 \mathrm{~mm}$ long, linear.

Distribution - Probably endemic to western Ecuador.

Habitat - Humid lowland and submontane forest; altitudes up to $1200(-1500$ ?) $\mathrm{m}$.

Notes -1 . This species belongs to a group of species, being hairy on most parts and with relatively small leaves and figs, occurring in Central America and the Pacific Coastal region of South America, and comprising, e.g., F. colubrinae Standl., F. costaricana (Liebm.) Miq., and F. hartwegii (Miq.) Miq. It appears to be most closely related to $F$. hartwegii, from which it clearly differs in the more numerous lateral veins, (8-)10-12(-14) vs (4-)7-9 pairs, and the indumentum consisting of hairs distinctly different in length. On the smaller veins of the lower surface of the lamina short hairs are present whereas the indumentum is confined to the main veins or only to the midrib in F. hartwegii.

2. This species also resembles the Amazonian F. ursina Standl., of which the lamina is (sub)hispidulous and \pm scabrous above, the periderm of the twigs and epidermis of the petiole not flaking off, and the fig receptacle larger, $1.2-1.5 \mathrm{~cm}$ in diameter.

3. Collection E. Forero et al. 3486 (COL), from Colombia, Chocó, road San José del Palmar-Nóvita, near Curundó, 250 m, 26 Feb. 1977, resembles the collections of this species included in the Identification List, but is distinct in the presence of only one type of hairs, relatively long brown ones, and persistent epidermis of the petiole and periderm of the leafy twig. It is not certain whether this collection can be included in the new species.

\section{Ficus ecuadorensis C.C. Berg, spec. nov. - Fig. 2}

Fico tonduzii similis, stipulis petiolisque brevioribus, ficus receptaculo dense hirtello ad subvelutino differt. - Typus: Dik 396 (holo QCNE; iso BG, MO), Ecuador, Orellana, Parque Nacional Yasuní, Maxus road, km. 46, Pozo Petrolero Capiron, 6-16 Sept. 1993.

Tree to $28 \mathrm{~m}$ tall, with buttresses. Leafy twigs 3-6 mm thick, brown puberulous to hirtellous, periderm flaking off. Lamina elliptic to suborbicular to obovate (or to oblong), $9-21(-31)$ by $5.5-10(-21) \mathrm{cm}$, subcoriaceous (to coriaceous), apex short-acuminate to 


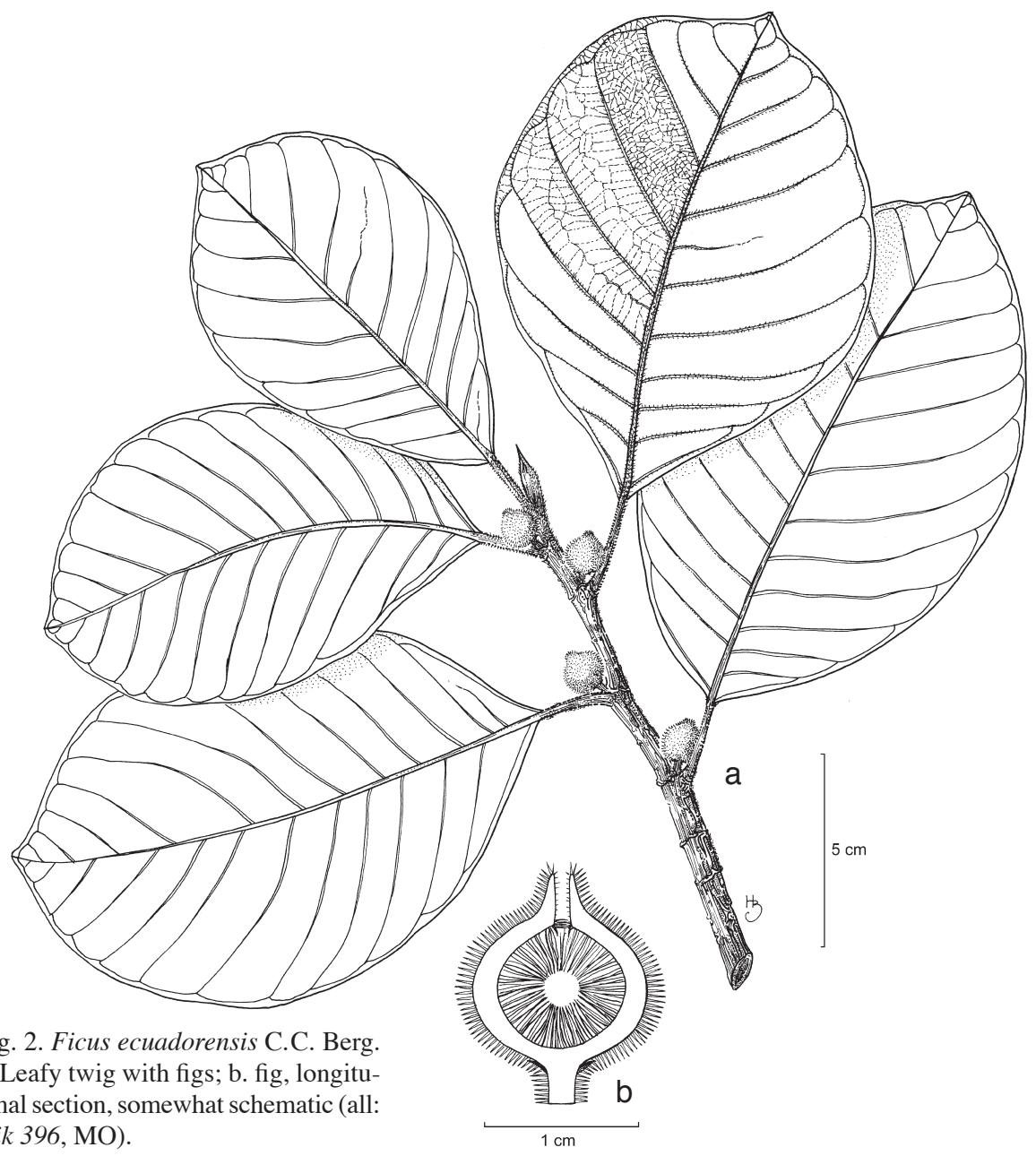

rounded, base obtuse to rounded to cordulate or to subcuneate, margin \pm revolute; upper surface hispidulous, scabrous, lower surface puberulous to hirtellous or to hispidulous, scabridulous; venation plane or \pm impressed above; lateral veins $8-14$ pairs, basal ones unbranched, running close to the margin, tertiary venation \pm irregularly scalariform to subreticulate, reticulum prominent; waxy glands in the axils of the basal lateral veins; petiole 1-3(-4) cm long, 2-2.5 mm thick, puberulous to hirtellous, the epidermis flaking off; stipules 1-1.5 cm long, brown to whitish strigillose, drying dark brown, caducous. Figs just below the leaves, solitary; peduncle $0.2-0.3 \mathrm{~cm}$ long; basal bracts $3,1-1.5 \mathrm{~mm}$ long; receptacle globose, c. $1 \mathrm{~cm}$ diam. when dry, densely white hirtellous to subvelutinous, the apex protracted; ostiole c. $1 \mathrm{~mm}$ diam., sunken, at the base of a c. $3 \mathrm{~mm}$ long tunnel. Flowers too young to be described.

Distribution - Probably endemic to Amazonian Ecuador.

Habitat - Humid forest; altitudes up to $1700 \mathrm{~m}$. 
Notes -1 . The species is distinct by the scabrous to scabridulous surfaces of a subcoriaceous lamina, the short stipules and peduncles, and/or the densely hairy fig receptacles. A sunken ostiole at the base of the tunnel in the apex of the receptacle is also found in several other species of the subsection Petensenses.

2. The fig receptacles in the type collection, the only one with figs, may not have reached the maximum size.

3 . In older laminas, the venation can become \pm impressed above.

4. A vernacular name is Caimato del monte (Clark et al. 5096).

\section{Ficus francoae C.C. Berg, spec. nov. - Fig. 3}

Fico casapiensi similis, petioli epidermide persistenti, bracteis basalibus intus glabris, bracteis duabus ostiolum claudentibus differt. - Typus: Franco \& Berg 4588 (holo HUA; iso BG), Colombia, Antioquia, Mun. San Luis, Río Claro, c. 350 m, 25 March 1994.

Tree to $15 \mathrm{~m}$ tall. Leafy twigs 3-4 mm thick, whitish strigillose (or also strigose on the scars of the stipules?) or glabrous; periderm flaking off. Lamina coriaceous, obovate to

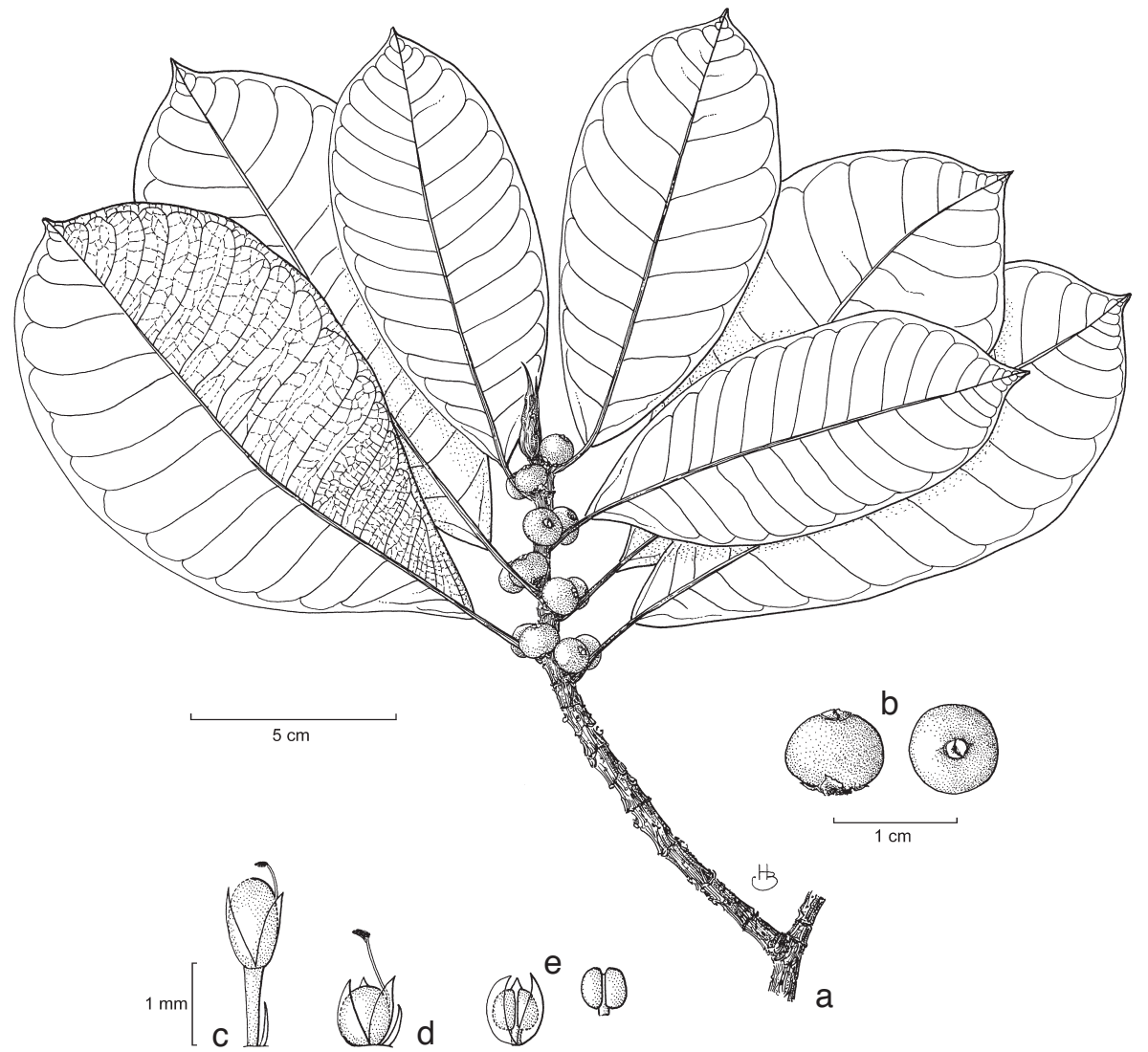

Fig. 3. Ficus francoae C.C. Berg. a. Leafy twig with figs; b. figs, showing basal bracts and ostiole; c. short-styled pistillate flowers; d. long-styled pistillate flowers; e. staminate flower and stamen (all: Franco \& Berg 4588, BG). 
subobovate, $11-19$ by $5-8 \mathrm{~cm}$, apex short-acuminate, base obtuse to subcuneate; upper surface glabrous, lower surface glabrous; lateral veins 12-17 pairs, the basal pair up to $1 / 20-1 / 10$ the length of the lamina, unbranched, tertiary venation reticulate; petiole $0.5-3.5 \mathrm{~cm}$ long, 2-3 mm thick, glabrous, the epidermis persistent; stipules 1-2.5 $\mathrm{cm}$ long, glabrous or whitish strigose at the base outside, glabrous inside, caducous or subpersistent. Figs axillary, sessile; basal bracts 2, c. $3 \mathrm{~mm}$ long, strigillose to glabrous outside, glabrous inside; receptacle (depressed-)globose, $0.6-0.8 \mathrm{~cm}$ diam. when dry,

Fig. 4. Ficus casapiensis (Miq.) Miq. a. Leafy twigs with figs; b. fig; c. short-styled pistillate flower and interfloral bract; $d$. long-styled pistillate flower; e. staminate flower and stamen (all: Berg et al. 1604, $\mathrm{BG})$.

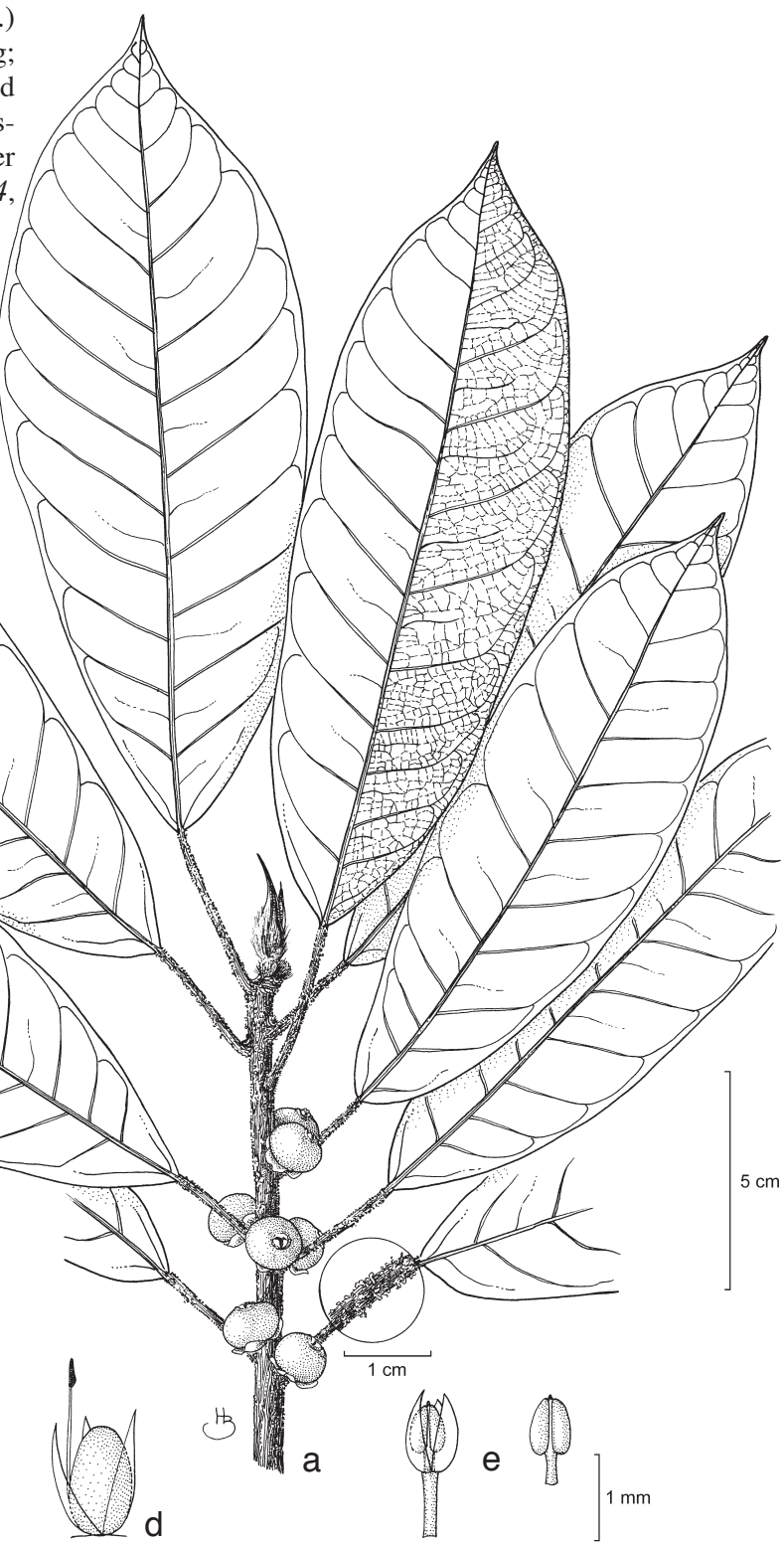


c. $1.2 \mathrm{~cm}$ diam. when fresh, glabrous, yellowish at maturity; ostiole c. $2 \mathrm{~mm}$ diam., plane, closed by 2 bracts; internal hairs absent. Staminate flowers (sub)sessile; tepals 3, 0.6-0.7 mm long; stamen 1, anther c. $0.5 \mathrm{~mm}$ long. Long-styled pistillate flowers sessile; tepals 3, 0.6-0.7 mm long; style $0.8-1 \mathrm{~mm}$. Short-styled pistillate flowers up to $1 \mathrm{~mm}$ long pedicellate; tepals 3, 0.6-0.7 mm long; style $0.4-0.6 \mathrm{~mm}$ long. Interfloral bracts few, $0.4-0.5 \mathrm{~mm}$ long.

Distribution - Known from Colombia (Antioquia) and the adjacent part of Panama (Darién).

Habitat - Humid forest at low altitudes.

Notes -1 . This species resembles $F$. casapiensis (Miq.) Miq. (see Fig. 4), from which it differs in the persistent epidermis of the petiole, the glabrous inner surface of the basal bracts, and two bracts closing the ostiole.

2 . The geographical gap between the ranges of $F$. casapiensis and $F$. francoae is partly filled by the related $F$. quichuana.

3. These related species are keyed out under F. quichuana.

\section{Ficus jacobii Vázq. Avila}

Ficus jacobii Vázq. Avila in Vázquez Avila et al. (1986) 201. - Type: Hutchinson \& Wright 6708 (holo F; iso G, GH, LE, MICH, MO, NY, P, US), Peru, Lambayayeque, 17 km E of Olmos, 1964.

Tree to $30 \mathrm{~m}$ tall. Leafy twigs $5-10 \mathrm{~mm}$ thick, angular, \pm densely pale brown to whitish puberulous to hirtellous, glabrescent; periderm persistent. Lamina coriaceous, oblong to elliptic, 7-28 by $3-14 \mathrm{~cm}$, apex short-acuminate to rounded, base cordate to rounded; upper surface whitish puberulous to tomentellous, mainly on the main veins, lower surface \pm densely pale brown to whitish tomentose to puberulous on the veins; lateral veins (7-)9-14(-20) pairs, the basal pair up 1/20-1/6 the length of the lamina, mostly branched, with 1-5 pairs of smaller lateral veins below the main pair, the tertiary venation reticulate; petiole $0.5-4(-8$ ?) $\mathrm{cm}$ long, $2-3 \mathrm{~mm}$ thick, whitish to pale brown puberulous, the epidermis persistent; stipules $1-3 \mathrm{~cm}$ long, densely to sparsely brownish to yellowish subsericeous to hirtellous outside, glabrous inside, caducous. Figs axillary, in pairs, subsessile or with a peduncle $0.1-0.3(-0.4) \mathrm{cm}$ long; basal bracts $2-2.5 \mathrm{~mm}$ long, whitish to brownish puberulous outside, glabrous inside; receptacle subglobose, $0.7-1.3 \mathrm{~cm}$ diam. when dry, densely pale brown to whitish puberulous to tomentellous to (sub)glabrous; ostiole c. $2 \mathrm{~mm}$ diam., \pm prominent to flat, surrounded by a circular or triangular rim, closed by 3 or 4 bracts; internal hairs present, rather abundant to sparse.

Note - Two subspecies can be recognized.

\section{a. subsp. jacobii}

Lamina $5-14$ by $3-7 \mathrm{~cm}$, apex rounded to very shortly acuminate; lateral veins (8-) 12-15 pairs, with 1 pair of smaller veins below the main pairs of basal lateral veins; petiole $0.5-1(-2) \mathrm{cm}$ long; stipules $1-1.5 \mathrm{~cm}$ long, densely brownish to yellowish subsericeous to hirtellous outside. Fig receptacle $0.7-1.2 \mathrm{~cm}$ diam. when dry, densely whitish puberulous to tomentose; peduncle $0-0.1(-0.4) \mathrm{cm}$ long.

Distribution - Ecuador (Loja) and Peru (Cajamarca, Lambajeque, Tumbes).

Habitat - Dry forest; altitudes between 500 and 2100 m. 
b. subsp. mantana C.C. Berg, subsp. nov. - Fig. 5

A subspecie typica plerumque laminis maioribus, venis lateralibus plus numerosis, stipulis longiorobus differt. - Typus: Neill et al. 11870 (holo QCNE; iso BG), Ecuador, Manabí, Prov. Manta, Parroquia San Lorenzo, 2 km E of Santa Rosa, 140 m, 8 May 1999.

Lamina $8-28$ by $4-14 \mathrm{~cm}$, apex shortly acuminate; lateral veins $(10-) 12-15(-20)$ pairs, with $1-5$ pairs of smaller veins below the main pairs of basal lateral veins; petiole (0.5-)1.5-4(-8?) cm long; stipules $1.5-3 \mathrm{~cm}$ long, densely to sparsely brownish to yellowish subsericeous outside. Fig receptacle $0.6-1 \mathrm{~cm}$ diam. when dry, densely minutely white puberulous to subglabrous; peduncle $0.1-0.3 \mathrm{~cm}$ long.

Fig. 5. Ficus jacobii Vázq. Avila subsp. mantana C.C. Berg. a. Leafy twig with figs; b. figs; c. long-styled pistillate flower and interfloral bract; $d$. short-styled pistillate flower and interfloral bract (all: Neill et al. 11870, BG).

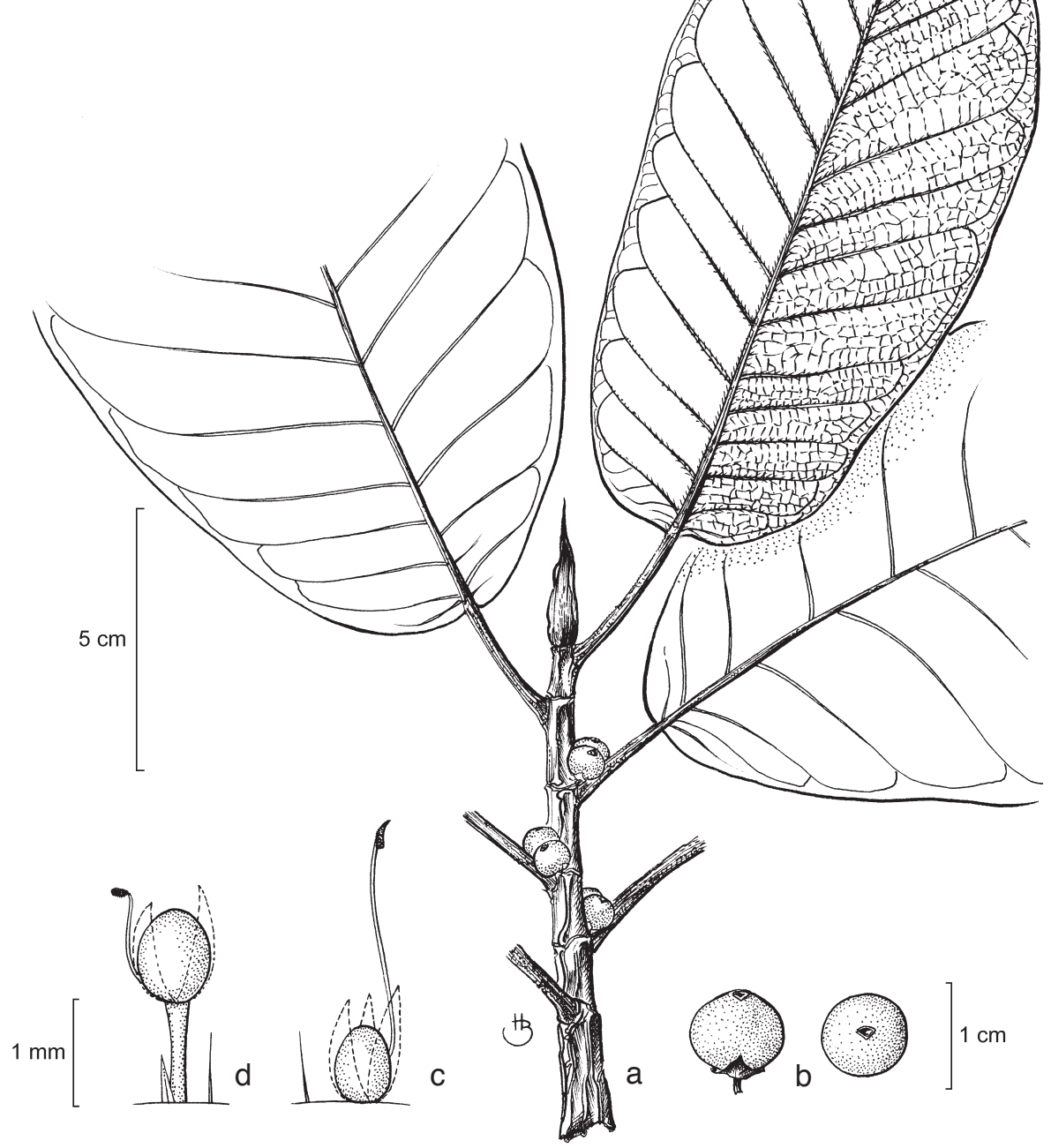


Distribution - Ecuador (El Oro, Esmeraldas, Loja, Guayas, Manabí).

Habitat - Dry to humid forest; altitudes mostly below $500 \mathrm{~m}$, in Loja up to c. $1000 \mathrm{~m}$, where the subspecies may co-occur, as observed (9 December 2006) near Catacocha.

Notes -1 . This subspecies differs from the typical one in the mostly larger leaves with mostly more lateral veins and a more clearly acuminate apex, and longer stipules. The subspecies is also ecologically different in occurring at low altitudes and probably also by occurring also in humid forest.

2. The identity of the sterile and probably juvenile specimen, Cornejo et al. 6963, with up to $8 \mathrm{~cm}$ long petioles is somewhat uncertain.

\section{Ficus loxensis C.C. Berg, spec. nov. - Fig. 6}

Fico maxima similis, exempli gratia in bracteis basalibus caducis et ficus receptaculo pustulato differt. - Typus: Cerón \& Ocampo 11852 (holo MO; iso BG, QCNE n.v), Ecuador, Loja, Cantón Loja, Vilcabamba, Yamburara, 2500 m, 4 Sept. 1990.

Tree to $25 \mathrm{~m}$ tall. Leafy twigs $2-3 \mathrm{~mm}$ thick, minutely white puberulous; periderm flaking off. Lamina oblong to subovate, $7-17$ by $1.5-7 \mathrm{~cm}$, coriaceous, apex subacuminate to subacute, base obtuse, margin almost flat; upper surface glabrous, lower surface glabrous or minutely white puberulous (and with submicroscopic whitish to brownish ellipsoid to brown moniliform pluricellular trichomes), smooth; venation plane above; lateral veins $10-16$ pairs, the basal ones hardly distinct, up to $1 / 20-1 / 10$ the length of the lamina, unbranched, tertiary venation reticulate; waxy glands in the axils of the basal lateral veins or unclear (possibly represented by discolorations at the transitions of midrib and petiole); petiole 1-3 cm long, 1.5-2.5 mm thick, sparsely and minutely white puberulous to glabrous, the epidermis flaking off; stipules 2-4 $\mathrm{cm}$ long, glabrous or minutely white puberulous at the base, drying brown, caducous. Figs axillary and just below the leaves, solitary; peduncle $0.8-1 \mathrm{~cm}$ long, minutely white puberulous; basal bracts 3, verticillate or \pm scattered, 2-3 $\mathrm{mm}$ long, (sooner or later) caducous; receptacle subglobose, $1.5-1.8 \mathrm{~cm}$ diam. when dry, \pm clearly pustulate, minutely white puberulous, up to $0.5 \mathrm{~cm}$ long stipitate or non-stipitate, ostiole c. $2 \mathrm{~mm}$ diam., \pm prominent (in a convex to slightly concave apex) or sunken in a 2-3 $\mathrm{mm}$ long tunnel; wall 2-3 mm thick; internal hairs present, minute and rather sparse, or absent. Staminate flowers numerous, c. $2 \mathrm{~mm}$ long pedicellate, the pedicel often with a (displaced) basal bract; tepals 3, c. $2 \mathrm{~mm}$ long, free; stamens 2, anther c. 1.5 mm long. Pistillate flowers: tepals 3, lanceolate, c. $3 \mathrm{~mm}$ long; long-styled flowers sessile, style $0.8-1.2 \mathrm{~mm}$ long, the stigma bifid, the stigmatic arms unequal in length; short-styled flowers 1-3 mm long pedicellate, style $0.2-0.4 \mathrm{~mm}$ long, the stigma bifid, the stigmatic arms unequal in length. Interfloral bracts 3-4 $\mathrm{mm}$ long, often some on pedicels of staminate flowers.

Distribution - Known from northern Peru and Ecuador.

Habitat - Andean forest; altitudes between c. 1700 and $2500 \mathrm{~m}$.

Notes -1 . This species resembles F. maxima Mill., from which it differs, e.g., in the usually unclear waxy glands, the (always?) caducous basal bracts, the pustulate surface of the receptacle, the longer stigmata of the short-styled flowers, the consistent presence of two stigmatic arms, and minute brown pluricellular trichomes on the lamina beneath. 
2. This species is an element of montane forest, whereas F. maxima is a lowland species.

3. This species also show similarities to F. mutisii, as in the dimensions of the lamina and the presence of brown minute moniliform pluricellar trichomes, but it clearly differs in the exfoliating epidermis of the petiole.

Fig. 6. Ficus loxensis C.C. Berg. a. Leafy twig with figs; b. figs; c. ostiole; d. staminate flower with pedicellar bract; e. shortstyled pistillate flower; $\mathrm{f}$. long-styled pistillate flower (a-c: Cerón et al. 11852, BG; d-f: Young 4069, MO).

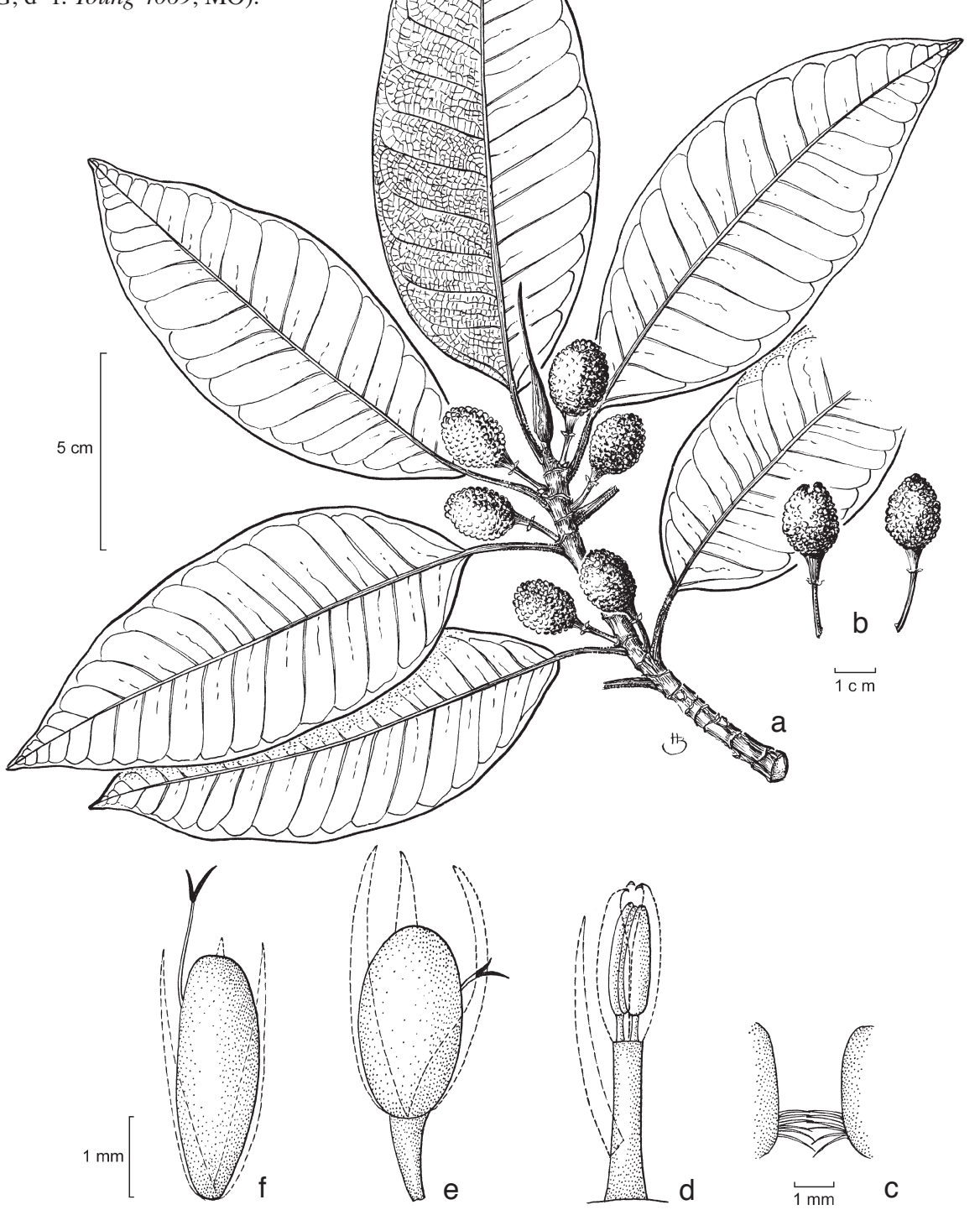


6. Ficus maximoides C.C. Berg, spec. nov. - Fig. 7

Fico maxima similis, exempli gratia in stipulis longioribus, lamina oblonga ad lanceolata differt. - Typus: Rodríguez et al. 1574 (holo MO; iso BG, HUT n.v.), Peru, Amazonas, Prov. Condorcanqui, Distrito El Cenepa, Mamayaque, 20 Feb. 1997.

Tree to $20 \mathrm{~m}$ tall (or shrub). Leafy twigs $2-5 \mathrm{~mm}$ thick, minutely white puberulous or glabrous; periderm flaking off. Lamina (sub)coriaceous, oblong to lanceolate, $(6-) 10-18(-23)$ by (1-)2-4.5(-6) cm, apex (sub)acuminate, base obtuse to cuneate,

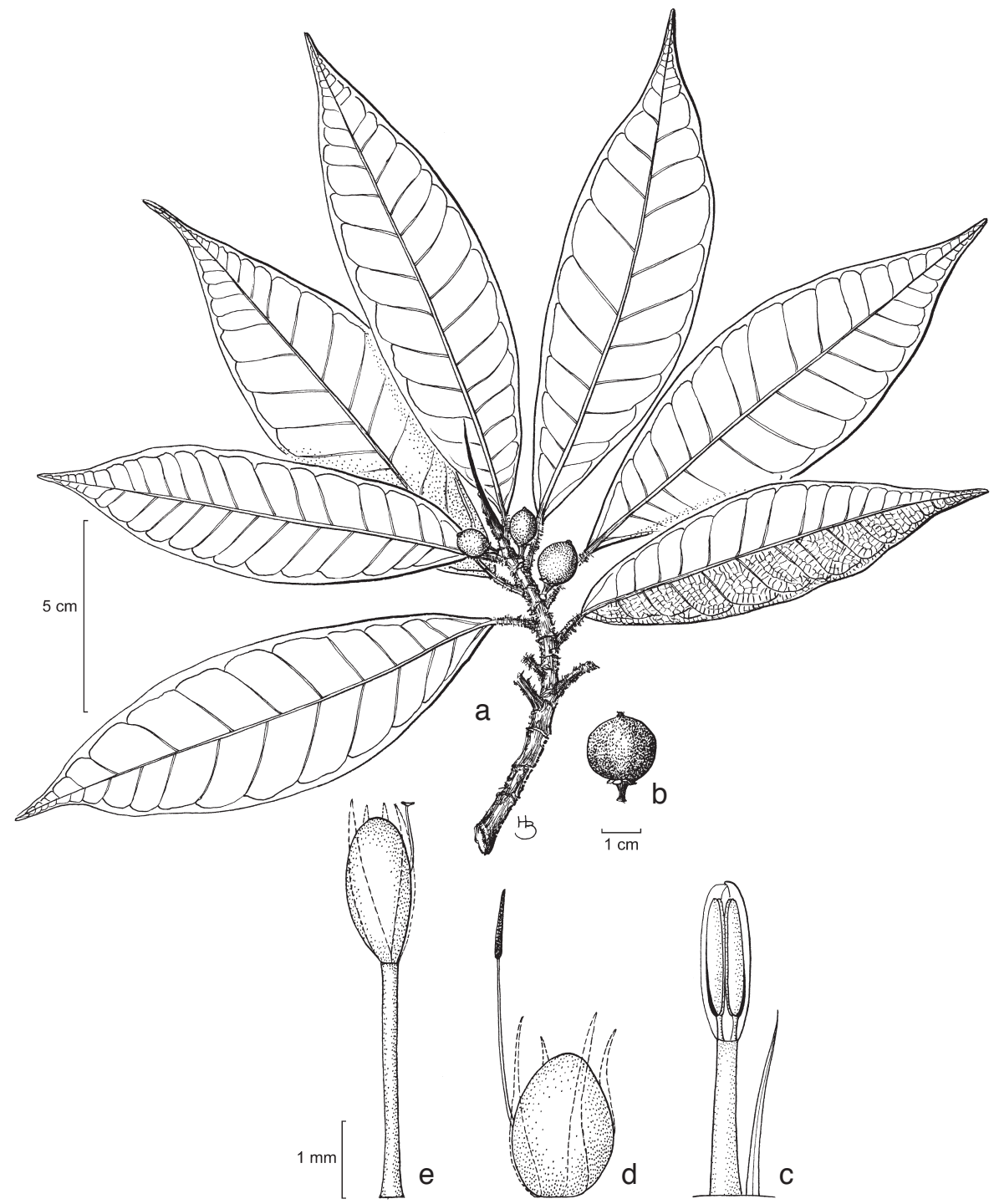

Fig. 7. Ficus maximoides C.C. Berg. a. Leafy twig with figs; b. fig; c. staminate flower; d. longstyled pistillate flower; e. short-styled pistillate flower (a: Campos et al. 3183, BG; b-e: Rodríguez. et al. 1574, BG). 
margin flat; upper surface glabrous, lower surface glabrous, smooth; midrib reaching the apex, lateral veins $10-15(-17)$ pairs, curved to almost straight, the basal pair distinct by the angle of departure, $1 / 20-1 / 10$ the length of the lamina, below the main pairs a pair of smaller lateral veins, tertiary venation largely parallel to the lateral veins to reticulate (towards the margin); waxy glands in the axils of the basal lateral veins; petiole 1-3.5 cm long, 1-2 mm thick, minutely white puberulous to glabrous, the epidermis flaking off (sometimes in large annular flakes); stipules $2-4(-5.5) \mathrm{cm}$ long, glabrous, caducous. Figs axillary, solitary; peduncle $0.2-0.7 \mathrm{~cm}$ long; basal bracts $3,1-1.5 \mathrm{~mm}$ long; receptacle subglobose to ellipsoid, 1-1.8 $\mathrm{cm}$ diam. when dry, up to $4.5 \mathrm{~cm}$ diam. when fresh, apiculate, white puberulous, at maturity greenish; ostiole 1-2 mm diam., prominent; wall up to $7 \mathrm{~mm}$ thick. Staminate flowers up to $1.5 \mathrm{~mm}$ long pedicellate with $0-2$ bracts; tepals $2-5 \mathrm{~mm}$ long, cucullate, stamens 2 , anther c. $1.5 \mathrm{~mm}$ long, pistillode present, short-subulate. Short-styled pistillate flowers up to $3 \mathrm{~mm}$ long pedicellate, (always?) without pedicellar bracts, tepals 4, c. $2 \mathrm{~mm}$ long, style including stigma $0.8-1 \mathrm{~mm}$ long, stigma 2-lobed to subpeltate. Long-styled pistillate flowers sessile; tepals 4, 2-2.5 mm long, style including stigma c. $3 \mathrm{~mm}$ long, stigma simple. Fruits c. $2 \mathrm{~mm}$ long, ellipsoid to ovoid, smooth. Interfloral and pedicellar bracts c. $2.5 \mathrm{~mm}$ long.

Distribution - Upper Amazon Basin, from Acre (Brazil) to northern Peru, possibly extending to Ecuador (Orellana).

Habitat - In humid forest; altitudes up to c. $1300 \mathrm{~m}$.

Notes -1 . This species is probably closely related to F. maxima Mill., from which it differs in the long stipules and the lanceolate lamina. The fig receptacle becomes larger than usual in F. maxima.

2. The material included in this species is quite uniform.

3. Narrow leaves are sometimes found in F. maxima, e.g., in Venezuela (Bolívar, Distrito Cedeno, H. van der Werff et al. 7767, BG), but they differ in features such as a scabrous lower surface of the lamina, shorter stipules and/or longer peduncles.

\section{Ficus pastasana C.C. Berg, spec. nov. - Fig. 8}

Fico eximia similis, foliis infra venis lateralibus nonnullis glandibus ceraceis additis, stigmatibus bifidi non coherentibus differt. - Typus: Zak et al. 5094 (holo QCNE; iso BG), Ecuador, Pastaza, Cantón Pastaza, Pozo Petrolero Ramirez, 20 km S of Curaray, 300 m, 21-28 Feb. 1990.

Tree to $30 \mathrm{~m}$ tall, terrestrial, with buttresses. Leafy twigs 5-7 $\mathrm{mm}$ thick, white (to brownish) puberulous to tomentose; periderm flaking off. Lamina coriaceous, oblong (to faintly subpandurate), $15-24$ by $6.5-13 \mathrm{~cm}$, apex short-acuminate, base (widely) cordate; upper surface glabrous, lower surface glabrous or whitish puberulous to subtomentose; lateral veins $12-15$ pairs, some branched or furcate far from the margin, basal pair up to $1 / 10-1 / 8$ the length of the lamina, branched, tertiary, venation largely scalariform; small waxy glands in slit-shaped extensions of the axils of several lateral veins; petiole 4-8(-16) cm long, 1.5-2.5 mm thick, glabrous or sparsely whitish puberulous to subtomentose, the epidermis persistent or flaking off (when older?); stipules 1-2 cm long, glabrous or ciliolate, caducous or subpersistent on shoot-apices 


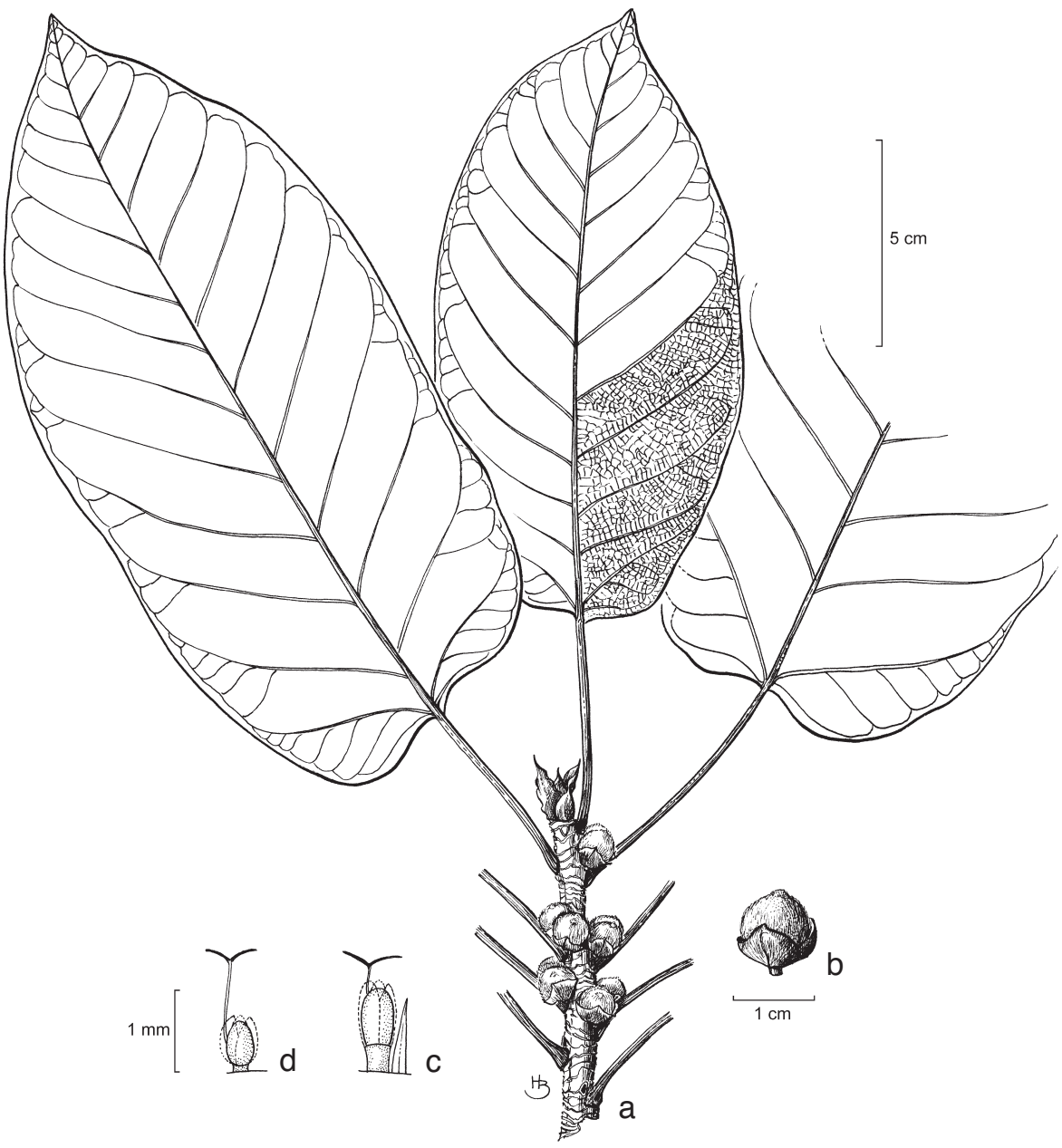

Fig. 8. Ficus pastasana C.C. Berg. a. Leafy twig with figs; b. fig; c. short-styled pistillate flower and interfloral bract; d. long-styled pistillate flower (all: Zak et al. 5094, BG).

with short internodes. Figs axillary, in pairs, with a peduncle up to $0.1 \mathrm{~cm}$ long; basal bracts 2, 5-15 mm long, (minutely) white puberulous to subsericeous to subvillous outside, white subsericeous inside; receptacle subglobose, c. $2 \mathrm{~cm}$ diam. when dry, white subsericeous to villous; colour at maturity unknown; ostiole 1-1.5 mm diam., flat, invisible because of dense white hairs; internal hairs absent. Staminate flowers not seen. Pistillate flowers: tepals 3, 0.5-0.8 mm long, with rounded apex; stigmas 2, 0.3-0.5 mm long, equally long, not coherent; short-styled flowers subsessile to up to $0.3 \mathrm{~mm}$ long pedicellate, style $0.3-0.4 \mathrm{~mm}$ long; long-styled flowers (sub) sessile, style $0.6-0.8 \mathrm{~mm}$ long. Interfloral bracts $\mathrm{c} .1 \mathrm{~mm}$ long.

Distribution - Upper Amazon Basin, known from southern Peru and from Ecuador (Pastaza) and might also occur in Colombia. 
Habitat - In humid forest at low altitudes.

Notes -1 . This new species is not only distinct by the additional waxy glands, but also by the two about equally long, not cohering stigmas, not yet found in any other species of subg. Urostigma.

2. It is remarkable that Ficus paludica Standl., which sometimes also has additional glands, although less in number, do have normal (Urostigma) stigmata.

3. The parts of leafy twigs with some short internodes and the subpersistent stipules indicate intermittent growth. These parts do not bear normal leaves, only reduced (caducous?) ones and subpersistent stipules forming a 'terminal bud'.

4. The frequent occurrence of waxy glands in the axils of lateral veins is unusual in subg. Urostigma. The trees may not be hemi-epiphytic, but terrestrial like in F. paludica. Whether the two species share the same habitat, inundated lake- and riversides, is not yet certain.

5. Ficus paludica is known from the Guiana region, the Guianas, Venezuela (Delta Amacuro), Trinidad, and Brazil (Amapá) and from the Upper Amazon Basin, Colombia (Putomayo), Ecuador (Orellana), and Peru (Loreto, Madre de Dios).

6. Ficus paludica and F. pastasana resembles F. eximia Schott of eastern and Amazonian Brazil and Bolivia (Berg \& Villavicencio, 2003), which differs in the caducous basal bracts.

7. The presence of additional waxy glands is also shared with $F$. ypsilophlebia Dugand, in which the additional glands are more abundant.

8. The collections Foster et al. 6341 and Gentry 43669 differ from the other collections in the presence of indumentum on the lamina beneath and on the petiole. Foster's collection has mature figs c. $2 \mathrm{~cm}$ diam. when dry, densely whitish villous, and with basal bracts c. $1.5 \mathrm{~cm}$ long.

9. The Colombian collection T. Plowman \& H. Kennedy 22674 (US, Caquetá, Río Ortegueza, Puerto Lara, 24 January 1969) probably belongs to this species, although additional waxy glands are not clearly present and the periderm of the petiole is not clearly flaking off.

\section{Ficus popenoei Standl.}

Ficus popenoei Standl. (1929) 301. - Type: Standley 52688 (holo F; iso A, US), Honduras, Atlándida, near Tela, 8 Dec. 1927 to 20 March 1928.

Tree to $20 \mathrm{~m}$ tall. Leafy twigs (2-)3-8 $\mathrm{mm}$ thick, \pm angular, brown hirtellous to subtomentose to subhirsute, the hairs distinctly different in length; periderm persistent. Lamina (sub)coriaceous to chartaceous, oblong to elliptic to (sub)obovate, (3-) $8-21(-30)$ by $(1.5-) 4-12(-22) \mathrm{cm}$, apex rounded to obtuse (to short-acuminate), base cordate to rounded, margin entire to repand; upper surface brown to whitish hirtellous to (sub)hispidulous, \pm scabrous, lower surface brown to whitish hirtellous to subtomentose or to subhispidulous on the veins, \pm scabrous to smooth; lateral veins (4-)7-10 pairs, the basal pair branched (or unbranched), up to 1/6-1/4 the length of the lamina, the upper ones often furcate away from the margin, tertiary venation reticulate; petiole $0.5-2.5(-5) \mathrm{cm}$ long, $1.5-2.5 \mathrm{~mm}$ thick, brown tomentose to hirtellous to hirsute; stipules $0.4-0.8 \mathrm{~cm}$ long, brown hirsute to hirtellous or to subsericeous outside, glabrous 
inside, caducous. Figs axillary, in pairs or solitary, sessile or with a peduncle to $0.5 \mathrm{~cm}$ long; basal bracts 1-3 mm long; receptacle ellipsoid to oblongoid (to subobovoid), $1-3.5$ by $0.5-2.5 \mathrm{~cm}, \pm$ narrowed at the base or subglobose and $0.8-1.5 \mathrm{~cm}$ diam. when dry, densely brown hirtellous, sometimes ribbed, greenish (?) at maturity; ostiole 1-2 mm diam., flat, closed by 3 bracts; internal hairs present.

Note - The species is quite variable as with regard to the size and venation of the lamina and the shape and size of the fig receptacle. Two subspecies can be recognized, but not clearly defined.

\section{a. subsp. popenoei}

Ficus tolimensis Standl. (1937) 177. - Type: Lehmann 5805 (holo F!), Colombia, Tolima, Dolores, $500-1400 \mathrm{~m}$.

Lamina (3-) 8-21(-30) by $(1.5-) 4-12(-22) \mathrm{cm}$, apex rounded to obtuse to very shortly acuminate; lateral veins (4-)7-10 pairs. Fig receptacle ellipsoid to oblongoid to subobovoid (or subglobose), $1-3.5$ by $0.5-2.5 \mathrm{~cm}$ diam. when dry; peduncle $(0-) 0.2-0.5 \mathrm{~cm}$.

Distribution - From Belize through Central America through the Andean region to Bolivia.

Habitat - Humid forest; altitudes up to $1000 \mathrm{~m}$.

Note - The only collection with subglobose fig receptacles of c. $1.5 \mathrm{~cm}$ diam., thus with the shape normal in subsp. malacocarpa, but larger, is Schipp 1008 from Belize.

b. subsp. malacocarpa (Standl.) C.C. Berg, comb \& stat. nov.

Ficus malacocarpa Standl. (1937) 172. - Type: Persaud 100 (holo F; iso K), Guyana, Curita, Aug. 1924.

Ficus scabrida Pittier (1937) 68. - Type: Christ 49 (holo VEN; iso US), Venezuela, Lara, Maporito, near Baragua, 6 Oct. 1927.

Lamina (2.5-)5-16 by (1.5-)2.5-11 cm, apex rounded to shortly and bluntly acuminate; lateral veins (4-)6-8(-9) pairs. Fig receptacle subglobose (or obovoid) $0.8-1.4$ $\mathrm{cm}$ diam. when dry; peduncle $0-0.2 \mathrm{~cm}$ long.

Distribution - From the Guianas to northern Venezuela and the Amazon Basin, mainly the northern part.

Habitat - Forest at low altitudes.

Notes -1 . The fig receptacle is in the western part of the subspecies range (Colombia, western Venezuela) larger and more densely hairy than in the eastern part of the subspecies range.

2. One of the collections, G. Davidse et al. 27294 from Venezuela (Amazonas), has obovoid fig receptacles similar to those normally found in subsp. popenoei.

3. This subspecies can be easily confused with $F$. matiziana Dugand, which can be distinguished by the rim around the ostiole, by usually more numerous lateral veins, and the often smooth upper surface of the lamina with \pm impressed venation. 
9. Ficus quichuana C.C. Berg, spec. nov. - Fig. 9

Fico casapiensi similis, foliis infra vel costa basi indumento albescenti substrigoso, praesenti bracteorum ostiolarium superiorium duarum differt. - Typus: Palacios 2964 (holo QCNE; iso BG, NY), Ecuador, Napo, Río Napo, 8 km E of Puerto Mishuallí, 450 m, 7-16 Sept. 1988.

Tree to $18 \mathrm{~m}$ tall. Leafy twigs 3-8 $\mathrm{mm}$ thick, slightly angular to subterete, brownish to whitish strigillose and/or brownish to whitish strigose to subhirsute on the scars of the stipules; periderm flaking off. Lamina coriaceous, oblong to subobovate, 7-20

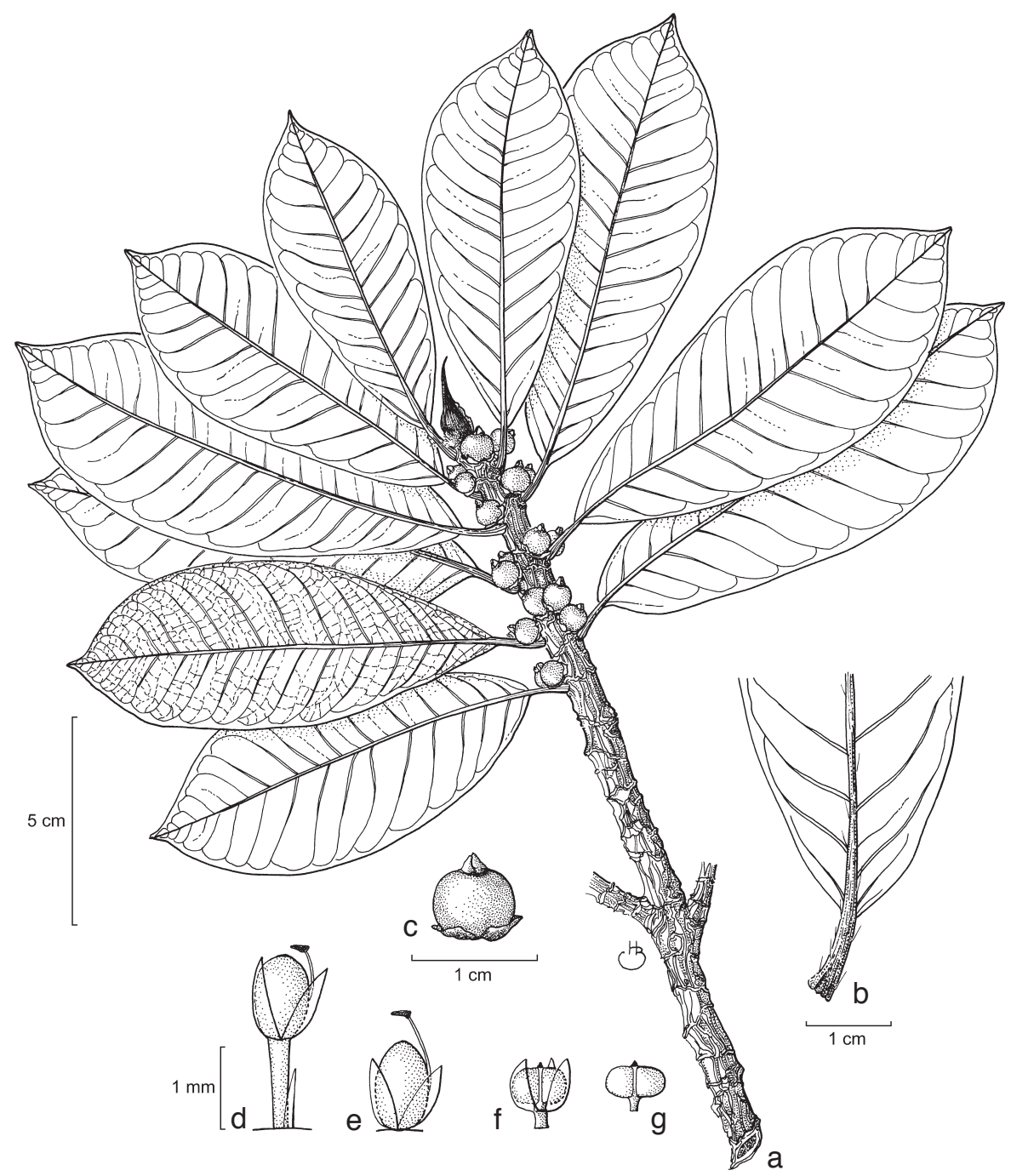

Fig. 9. Ficus quichuana C.C. Berg. a. Leafy twig with figs; b. basal part of leaf; c. fig; d. short-styled pistillate flower; e. long-styled pistillate flower; f. staminate flower; g. stamen (all: Palacios 2964, $\mathrm{BG})$. 
by $2.5-7 \mathrm{~cm}$, apex short-acuminate, base obtuse to rounded; upper surface glabrous, lower surface white strigose to subsericeous on the midrib, glabrescent (or glabrous?); lateral veins (8-)10-16 pairs, the basal pair up to $1 / 20-1 / 10$ the length of the lamina, unbranched, departing from the midrib at $0.3-0.5 \mathrm{~cm}$ from the base, 1 or 2 pairs of smaller lateral veins below the main pair, tertiary venation reticulate; petiole $0.5-$ $2.5(-3.5) \mathrm{cm}$ long, 2-3 mm thick, glabrous, brownish strigillose (or minutely whitish puberulous), the epidermis persistent (or flaking off); stipules 1-1.5 (on opening shoots $-6.5) \mathrm{cm}$ long, glabrous or brownish to whitish strigose at the base outside, glabrous inside, caducous. Figs axillary, in pairs, sessile, initially enclosed in up to $0.4 \mathrm{~cm}$ long strigose calyptrate bud covers; basal bracts 2, 2-3 mm long, often hairy at the base of the receptacle inside, whitish strigillose to glabrous outside; receptacle subglobose to ovoid, $0.4-0.7 \mathrm{~cm}$ diam. when dry, glabrous or sparsely and minutely white puberulous, red at maturity; ostiole c. $2 \mathrm{~mm}$ diam., umbonate, closed by 2 (or 3), often ciliolate bracts. Staminate flowers (sub)sessile; tepals 3, 0.6-0.7 mm long; stamen 1, anther c. $0.5 \mathrm{~mm}$ long, apiculate. Long-styled pistillate flowers sessile; tepals 3, 0.6-0.7 mm long; style $0.8-1 \mathrm{~mm}$ long. Short-styled pistillate flowers up to $1 \mathrm{~mm}$ long pedicellate; tepals 3, 0.6-0.7 mm long; style $0.4-0.6 \mathrm{~mm}$ long. Fruits with relatively thick exocarp. Interfloral bracts few, $0.4-0.5 \mathrm{~mm}$ long.

Distribution - Upper Amazon Basin, from southern Colombia (Caquetá) to northern Peru (Loreto, San Martín).

Habitat - Humid forest at low altitudes.

Notes -1 . This species differs from $F$. casapiensis (see Fig. 4) in the sparse to dense appressed white hairs on the midrib of the lamina beneath, sometimes only at its base. These hairs disappear with age and might be sometimes absent. Moreover, the ostiole is umbonate and closed by only two bracts, the figs are often smaller $(0.4-0.6 \mathrm{~cm}$ diam. when dry), and the epidermis of the petiole is often persistent.

2. This species, F. francoae (described above), F. casapiensis (see Fig. 4), F. trapezicola Dugand (see Fig. 10), and F. trianae Dugand, belong to a group of closely related species occurring in an area ranging from Panama to Bolivia and is characterized by brownish to whitish strigose leafy twigs, stipules, and basal bracts; the stipules are relatively large, up to $2.5-5 \mathrm{~cm}$ long, and often subpersistent. These species can be easily confused. They can be keyed out as follows:

1a. Lateral veins $5-9(-10)$, the basal pair up to $1 / 8-1 / 4$ the length of the lamina. - Pacific Coastal region of Ecuador and Colombia to Panama . . . . . F. trianae

b. Lateral veins (8-)10-20 pairs, the basal pair up to $1 / 20-1 / 10$ the length of the

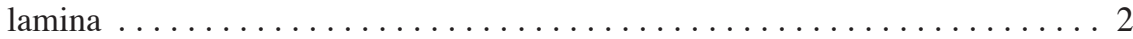

2a. Stipules strigose to subsericeous inside. - Amazonian Colombia, Ecuador, and

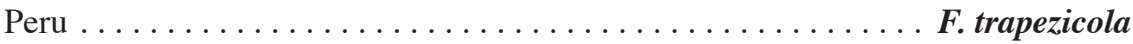

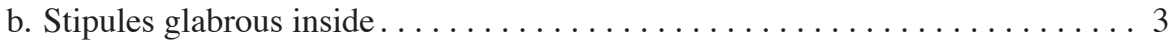

3a. Inner surface of the basal bracts glabrous. - Colombia (Antioquia) to Panama

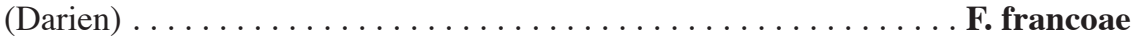

b. Inner surface of the basal bracts hairy at the base . . . . . . . . . . . 4

4a. Midrib with appressed whitish hairs beneath; fig receptacle subglobose to ovoid, 0.4-0.7 cm diam. when dry; ostiole umbonate, closed by 2 upper ostiolar bracts; epidermis of the petiole mostly persistent. - Amazonian Ecuador and Peru . . . . 
b. Midrib glabrous beneath; fig receptacle depressed-globose, 1-1.2 cm diam. when dry; ostiole flat to slightly prominent, closed by 3 upper ostiolar bracts; epidermis of the petiole flaking off. - Amazonian Peru and Bolivia ... F F casapiensis

3. The vernacular of name this species in Quichua is 'ango ila muyo'.

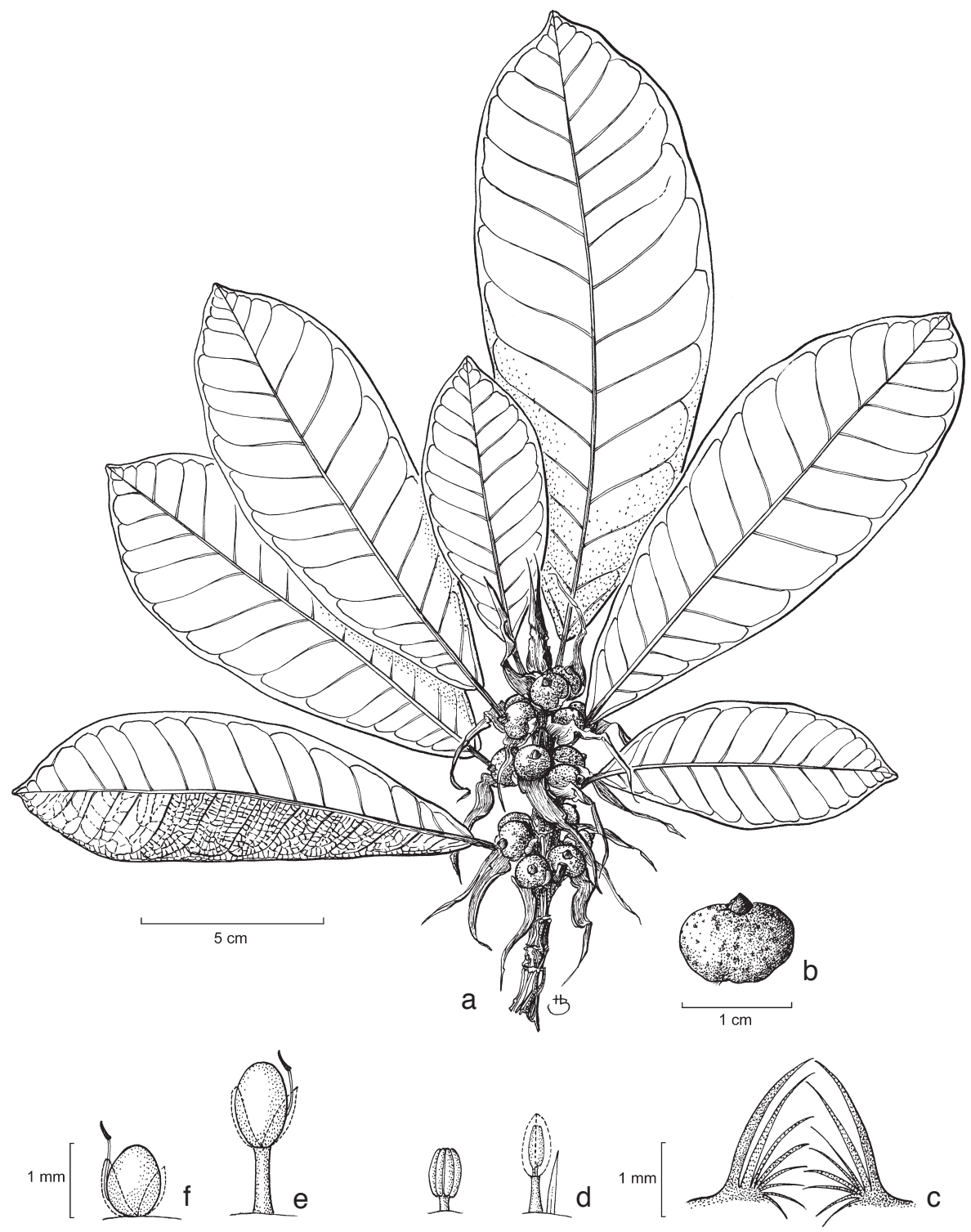

Fig. 10. Ficus trapezicola Dugand. a. Leafy twig with figs; b. fig; c. ostiolar bracts; d. staminate flower, stamen, and interfloral bracts; e. short-styled-pistillate flower; f. long-styled pistillate flower (all: Campos 752, BG). 
10. Ficus quistocochensis C.C. Berg, spec. nov. - Fig. 11

Fici schippii similis, ficis axillaribus sessilibus, foliis infra pilis patentibus tantum costae basi, petiole epidermide persistenti differt. - Typus: Vásquez \& Jaramillo 9458 (holo BG; iso NY), Peru, Loreto, Prov. Maynas, Quistococha, 27 Aug. 1987.

Tree to $10 \mathrm{~m}$ tall. Leafy twigs $2-4 \mathrm{~mm}$ thick, \pm angular, glabrous; periderm flaking off. Lamina coriaceous, elliptic to oblong to subobovate, $(3-) 6-11(-17)$ by (1.5-)3.5-6 $\mathrm{cm}$, apex shortly and bluntly acuminate, base rounded to cordulate, margin revolute towards the base; upper surface glabrous, lower surface sparsely minutely puberulous on the midrib, hirtellous to subtomentose at the base (below the waxy gland); lateral

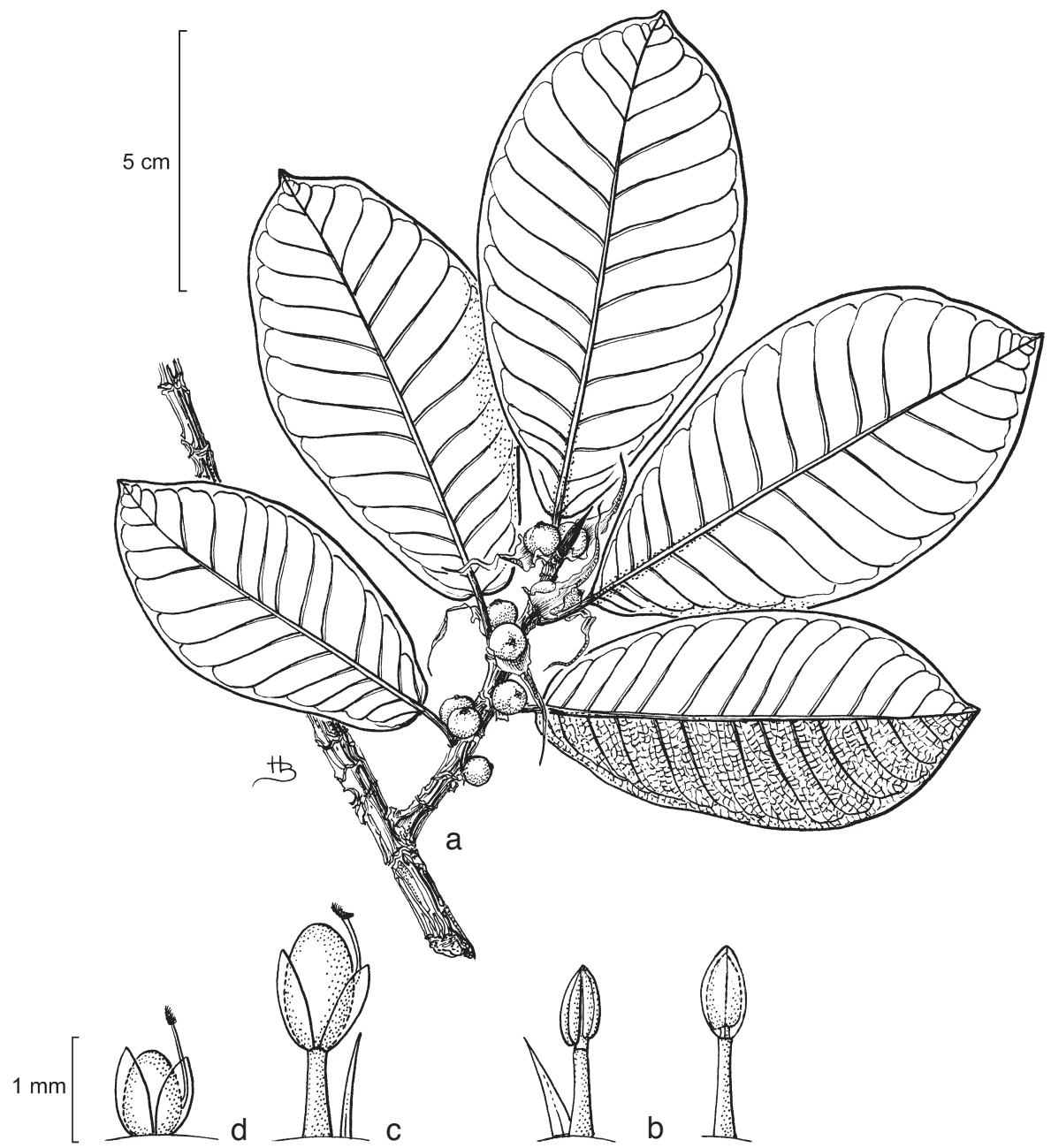

Fig. 11. Ficus quistocochensis C.C. Berg. a. Leafy twig with figs; b. staminate flower, stamen, and interfloral bract; c. short-styled pistillate flower; d. long-styled pistillate flower (all: Ayala 2057, BG). 
veins (7-) 10-15 pairs, the main basal pair up to $(1 / 20-) 1 / 10-1 / 6$ the length of the lamina, unbranched, ( 1 or) 2 pairs of smaller lateral veins below the main one, tertiary venation reticulate; petiole $(0.3-) 0.7-1.5 \mathrm{~cm}$ long, $1.5-2.5 \mathrm{~mm}$ thick, sparsely minutely puberulous and partly hirtellous, adaxially, and abaxially on the uppermost part, the epidermis persistent; stipules $1-2(-3.5) \mathrm{cm}$ long, minutely white puberulous outside, glabrous inside, subpersistent to caducous. Figs axillary, in pairs, sessile; basal bracts 2, 1.5-2 mm long, largely fused, minutely white puberulous outside, glabrous inside; receptacle subglobose, $0.4-0.5 \mathrm{~cm}$ diam. when dry, glabrous, ostiole c. $1.5 \mathrm{~mm}$ diam., flat to slightly prominent, closed by ( 2 or) 3 upper ostiolar bracts; internal hairs absent. Staminate flowers: pedicel 0.5-0.8 mm long; tepals 3, 0.6-0.8 mm long; stamen 1, anther $0.6-0.7 \mathrm{~mm}$ long, subapiculate. Long-styled pistillate flowers sessile; tepals 3, 0.8-1.2 mm long; style 0.8-1 mm long. Short-styled pistillate flowers up to $1 \mathrm{~mm}$ long pedicellate; tepals 3, 0.8-1 mm long; style 0.4-0.6 mm long. Interfloral bracts c. $0.5 \mathrm{~mm}$ long.

Distribution - Only known from the type locality.

Habitat - Forest (?) at low altitudes.

Notes -1 . This species resembles F. americana Aubl. subsp. guianensis (Desv.) C.C. Berg (2007) and F. schippii Standl. in the vegetative parts, but the figs are sessile and confined to the leaf axils. The hairs found at the base of the midrib resemble those occurring in F. schippii along the whole midrib; such hairs are absent in F. americana.

2. This species also shows similarities to $F$. vittata Vázq. Avila (Vázquez Avila et al., 1986) from which it differs in the absence of long hairs on the leafy twigs and the stipules and in the rounded to subcordulate base of the lamina.

\section{Ficus rimacana C.C. Berg, spec. nov. - Fig. 12}

Fico jacobii similis, ficis sessilibus, ostiolo umbonato differt. - Typus: Soukup 6077 (holo A), Peru, Lima, Central Highway, 64.5 km from Lima, valley of Río Rimac, 16001800 m, 15 Jan. 1969.

Tree to $8 \mathrm{~m}$ tall. Leafy twigs c. $4 \mathrm{~mm}$ thick, \pm angular and ribbed, white tomentose; periderm flaking off. Lamina coriaceous, oblong to subovate, $11-17$ by $5-7.5 \mathrm{~cm}$, apex (sub)acuminate, base (sub)cordate, margin entire, plane; upper surface white puberulous to tomentose on the main veins, lower surface densely brownish to whitish tomentose; lateral veins 9 or 10 pairs, the basal pairs loop-connected up to 1/4 the length of the lamina, branched, tertiary venation reticulate to (partly) subscalariform; petiole c. 1.5 $\mathrm{cm}$ long, $2 \mathrm{~mm}$ thick, white tomentose, the epidermis flaking off (?); stipules not seen. Figs axillary, in pairs, sessile; basal bracts 2, 3-4 mm long, white tomentose outside, glabrous inside; receptacle subglobose $0.8-1 \mathrm{~cm}$ diam. when dry, white tomentose, but the apex glabrous, colour at maturity unknown; ostiole c. $2 \mathrm{~mm}$ diam., umbonate, closed by 3 bracts; internal hairs absent. Staminate flowers: pedicel $0.3-1 \mathrm{~mm}$ long: tepals 3, 1-1.3 mm long; stamen 1, anther c. $0.8 \mathrm{~mm}$ long. Pistillate flowers: tepals 3, 1-1.8 mm long, stigma c. $0.3 \mathrm{~mm}$ long; long-styled flowers sessile; style c. $0.2 \mathrm{~mm}$ long; short-styled flowers: pedicel $0.3-1 \mathrm{~mm}$ long; style $0.4-1 \mathrm{~mm}$ long. Interfloral bracts abundant, 1.5-2 mm long.

Distribution - Only known from the type locality.

Habitat - Dry forest. 


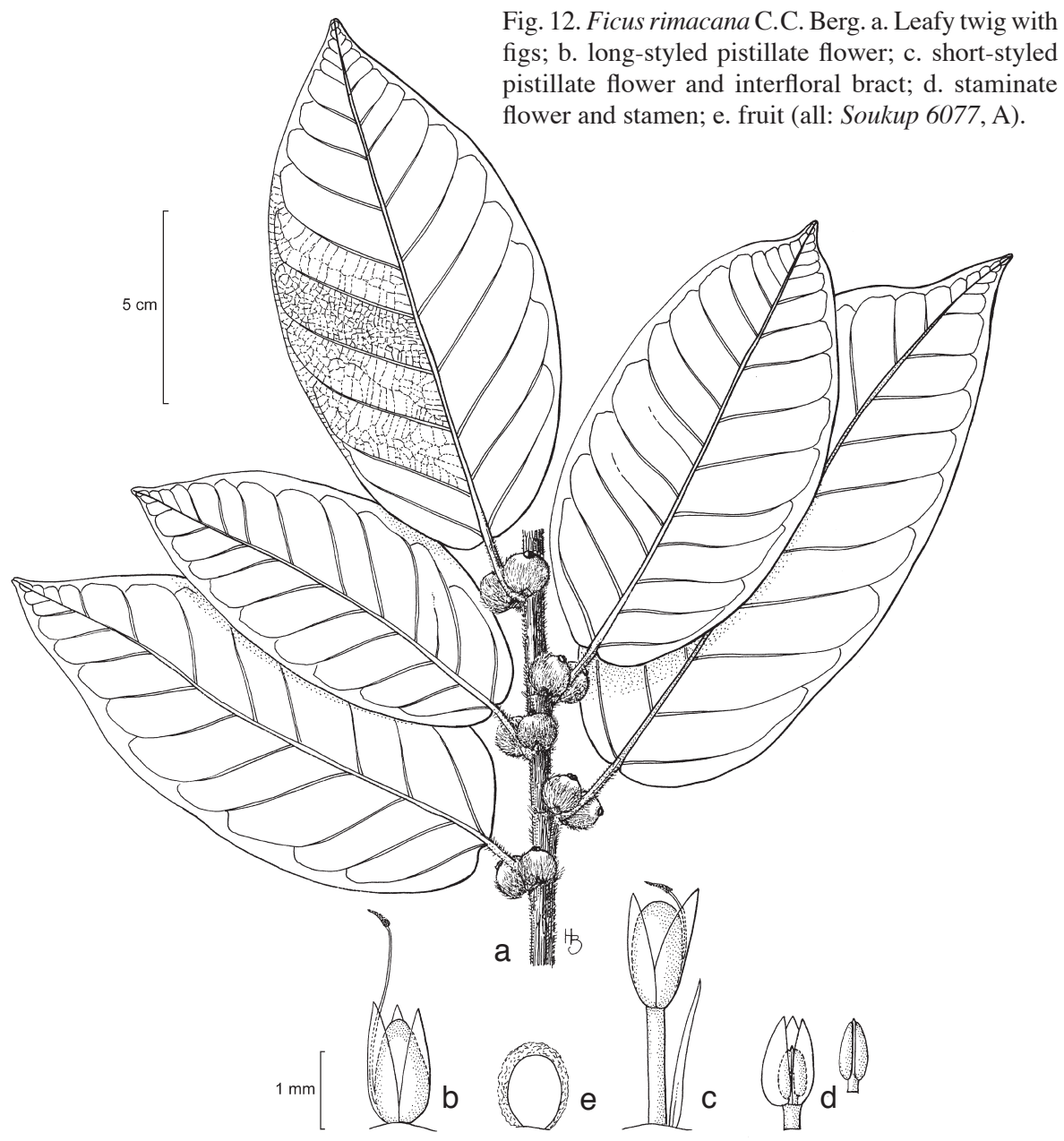

Note - This species is distinct by the densely tomentose lower leaf surface and white tomentose fig receptacle with an umbonate ostiole. Other species with \pm similar indumentum, as F. jacobii Vázq. Avila (Vázquez Avila et al., 1986) from south-western Ecuador and north-western Peru (see above) and F. mollicula Pittier from Venezuela, have either a (triangular) rim around the ostiole or less lateral veins.

\section{Ficus sumacoana C.C. Berg, spec. nov. - Fig. 13}

Fico casapiensi similis, stipulis indumento brunneo denso pilis longitudine aequali, foliis infra costa sine pilis longis differt. - Typus: Palacios 4746 (holo MO; iso AAU, GB, NY, QCNE n.v), Ecuador, Napo, Cantón Archidona, southern slopes of Volcán Sumaco, road Hollín-Loreto, km 45, 1000-1100 m, 10 Nov. 1989.

Tree to $40 \mathrm{~m}$ tall. Leafy twigs 5-6 $\mathrm{mm}$ thick, angular, minutely white puberulous and brown appressed-puberulous to -subpilose; periderm (sub)persistent. Lamina coria- 


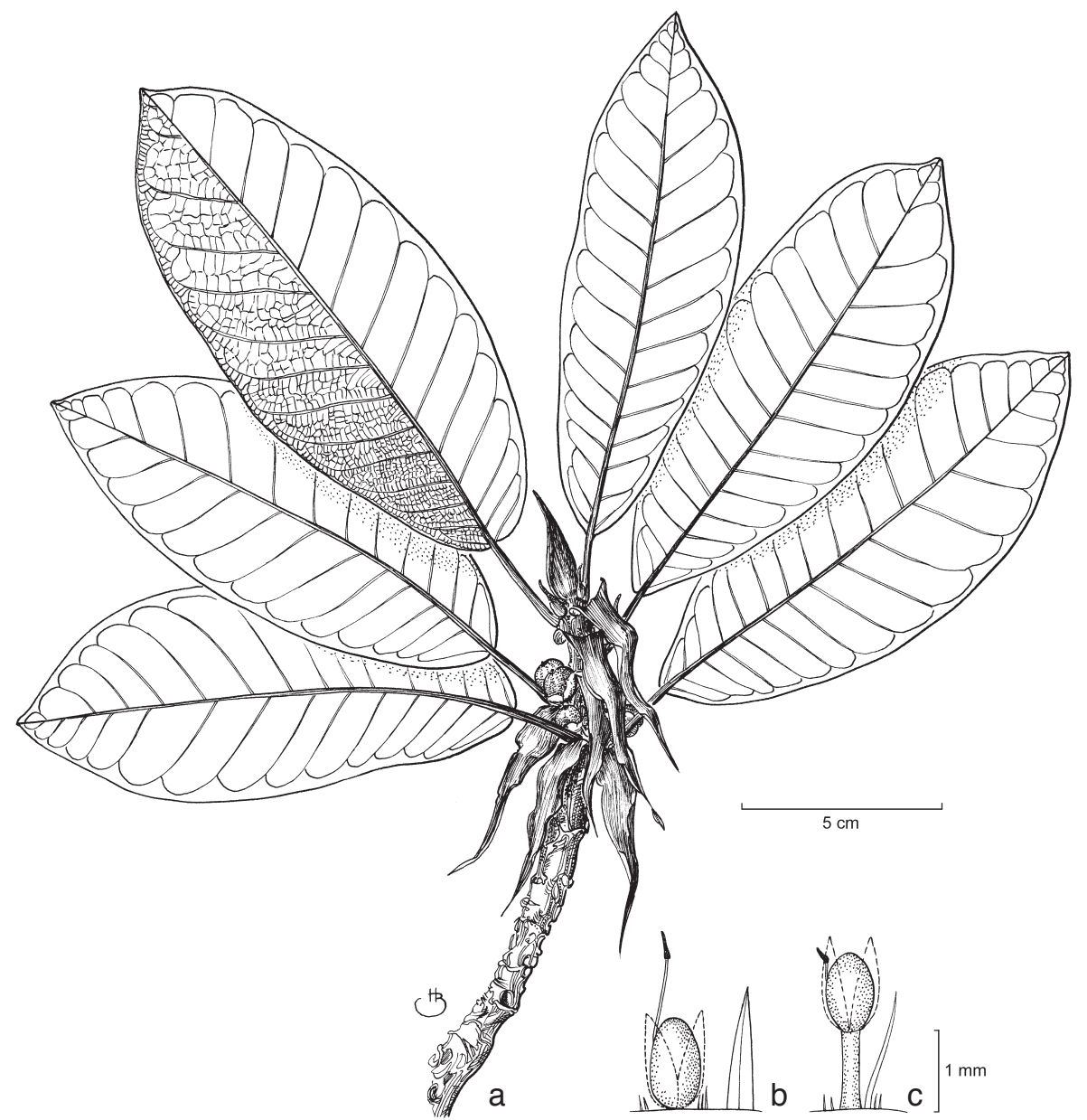

Fig. 13. Ficus sumacoana C.C. Berg. a. Leafy twig with figs; b. long-styled pistillate flower; c. shortstyled pistillate flower (all: Palacios 4746, AAU).

ceous, oblong, $8-17$ by $3-6 \mathrm{~cm}$, apex short-acuminate to obtuse, base rounded (to subcordulate), margin revolute towards the base; upper surface glabrous, lower surface glabrous except for the base of the midrib on which the indumentum of the petiole extends; lateral veins $14-16$ pairs, the basal pair up to $1 / 20-1 / 10$ the length of the lamina, unbranched, tertiary venation reticulate; petiole $1.3-2.2 \mathrm{~cm}$ long, c. $2.5 \mathrm{~mm}$ thick, minutely white puberulous and brownish to whitish subpilose, the epidermis flaking off; stipules $2.5-4 \mathrm{~cm}$ long, brown sericeous to densely appressed puberulous with hairs of similar length outside, glabrous inside, subpersistent. Figs axillary, in pairs, sessile, initially enclosed in up to $1.5 \mathrm{~cm}$ long, brownish appressed-puberulous bud covers; basal bracts 2, 4-5 mm long, brownish appressed-puberulous outside and ciliolate, glabrous inside; receptacle subglobose, $0.6-0.7 \mathrm{~cm}$ diam. when dry, glabrous, 
colour at maturity unknown; ostiole c. $1.5 \mathrm{~mm}$ diam., umbonate, surrounded by a low circular rim, closed by 3 upper bracts, these ciliolate; internal hairs present. Staminate flowers not seen. Short-styled pistillate flowers subsessile or with pedicels up to 1.5 mm long; tepals 3, free c. $1.2 \mathrm{~mm}$ long; style including stigma c. $0.6 \mathrm{~mm}$ long. Longstyled pistillate flowers (sub)sessile, tepals 3, c. $1.2 \mathrm{~mm}$ long; style including stigma 1.5-2 mm long. Interfloral bracts c. $3 \mathrm{~mm}$ long.

Distribution - Only known from Ecuador (Napo).

Habitat - Humid forest; altitudes between 1000 and $1250 \mathrm{~m}$.

Notes -1 . The species shows similarities to $F$. casapiensis, which ranges from Bolivia to Peru. It differs in the indumentum of the stipules consisting of brown hairs of equal length whereas the stipules of $F$. casapiensis has very short, partly retrorse hairs and much longer white hairs. Moreover, the for F. casapiensis characteristic long hairs on the midrib of the lamina beneath are lacking in $F$. sumacoana, which is probably also distinct by the subpersistent stipules and the well-developed calyptrate bud covers end closing the pairs of young figs.

2. The new species shows striking similarities to F. chaparensis C.C. Berg \& Villav. (Berg \& Villavicencio, 2003), known from a single collection collected in Cochabamba (Bolivia), which is mainly distinct in the presence of dense brownish indumentum on the lamina beneath and on the fig receptacle.

\section{Ficus valaria C.C. Berg, spec. nov. - Fig. 14}

Fico cervantesiana similis, laminis minoribus, venis lateralibus paucioribus, ficus minoribus sessilibus ad pedunculatis differt. - Typus: Monsalve B. 1227 (holo BG), Colombia, Valle, Bajo Calima, Buenaventura, Concesión Pulpapel, 100 m, 12 Nov. 1986.

Tree to $6 \mathrm{~m}$ tall. Leafy twigs $2-3 \mathrm{~mm}$ thick, \pm angular, young parts with \pm dense appressed dark red-brown submicroscopic pluricellular trichomes; periderm persistent or \pm flaking off. Lamina coriaceous, elliptic to oblong (to subovate), 4-7 by $1.5-3.5$ $\mathrm{cm}$, apex acuminate, base rounded to obtuse, margin flat; upper surface glabrous, lower surface with patent yellowish hairs laterally on the midrib, often clustered, numerous or few, and also abundant appressed brown submicroscopic pluricellular trichomes; midrib prominent above, lateral veins 7-10 pairs, the basal pair weakly developed up to $1 / 10$ the length of the lamina, unbranched, tertiary venation reticulate, waxy gland $0.3-0.5$ $\mathrm{cm}$ above the base of the lamina; petiole $0.6-1.3 \mathrm{~cm}$ long, 1-2 mm thick, glabrous, the epidermis persistent; stipules $1.5-2.5 \mathrm{~cm}$ long, glabrous, caducous. Figs axillary, in pairs, sessile or with a peduncle up to $0.2 \mathrm{~mm}$ long; basal bracts 2, c. $2 \mathrm{~mm}$ long, glabrous; receptacle subglobose, $0.4-0.7 \mathrm{~cm}$ diam. when dry, glabrous, colour at maturity unknown, ostiole c. $2 \mathrm{~mm}$ diam., flat to prominent, closed by 3 upper ostiolar bracts; internal hairs absent. Staminate flowers subsessile; tepals 3, c. $1 \mathrm{~mm}$ long; stamen 1, anther c. $0.6 \mathrm{~mm}$ long. Long-styled pistillate flowers sessile; tepals 3, 1-1.2 mm long; style $0.8-1 \mathrm{~mm}$. Short-styled pistillate flowers up to $0.5 \mathrm{~mm}$ long pedicellate; tepals 3, 1-1.2 mm long; style 0.2-0.4 mm long. Interfloral bracts c. $1 \mathrm{~mm}$ long.

Distribution - Coastal region of Colombia and Ecuador.

Habitat - Humid forest; altitudes up to $1800 \mathrm{~m}$.

Notes -1 . This species differs from $F$. cervantesiana Standl. \& L.O. Williams in the smaller leaves with a smaller number of lateral veins than in small leaves of 


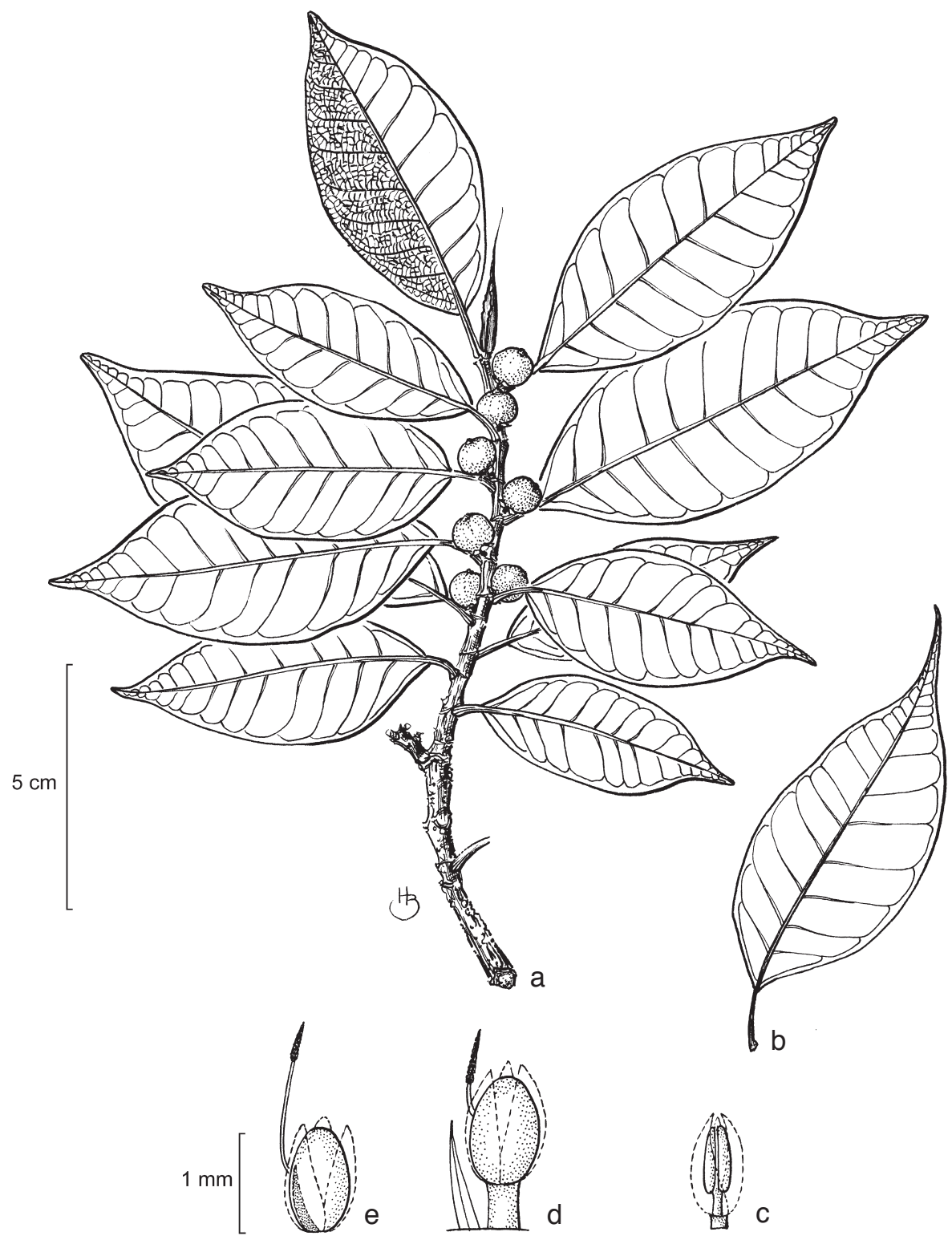

Fig. 14. Ficus valaria C.C. Berg. a. Leafy twig with figs; b. leaf; c. staminate flower; d. short-styled pistillate flower and interfloral bract; e. long-styled pistillate flower (all: Monsalve B. 1227, BG).

F. cervantesiana (with up to 10 pairs, rarely 9 pairs) and by smaller figs and basal bracts. The figs can be short-pedunculate, never so in F. cervantesiana.

2. It also resembles small-leaved specimens of $F$. hartwegii, from which it differs in the longer glabrous stipules and the patent hairs on the midrib of the lamina beneath. 


\section{ACKNOWLEDGEMENTS}

The diagnoses were translated into Latin by Dr. J.F. Veldkamp (Leiden). The preparation of the drawings was financed by the Olaf Grolle Olsen Foundation of the University of Bergen. The illustrations were drawn by Hendrieke Berg (Voss).

\section{REFERENCES}

Berg, C.C. 2006. The subdivision of Ficus subgenus Pharmacosycea section Pharmacosycea (Moraceae). Blumea 51: 147-151.

Berg, C.C. 2007. Proposals for treating four species complexes in Ficus subgenus Urostigma section Americanae (Moraceae). Blumea 52: 295-312.

Berg, C.C. \& J.P.P. Carauta. 2003. New species of Ficus (Moraceae) from Brazil. Brittonia 54: 236-250.

Berg, C.C. \& P. Franco Rosselli. 1996. New taxa and combinations in Moraceae and Cecropiaceae from Central and South America. Novon 6: 230-252.

Berg, C.C. \& X. Villavicencio. 2003. A new species of Ficus and a new species of Pseudolmedia (Moraceae) from Bolivia. Revista Soc. Boliv. Bot. 4: 75-79.

Pittier, H. 1937. Ensayo sobre la clasificación de las especies Venezolanas del género Ficus. Bol. Soc. Venez. Ci. Nat. 4, 30: 44-80.

Standley, P.C. 1929. Studies of American plants II. Publ. Field Mus. Nat. Hist., Bot. Ser. 4: 301345.

Standley, P.C. 1937. Studies of American plants VII. Publ. Field Mus. Nat. Hist., Bot. Ser. 17: $155-224$.

Vázquez Avila, M., C.C. Berg \& F. Kooy. 1986. New taxa of South American Ficus (Studies on the Flora of the Guianas 17). Acta Amazonica 14 (1/2), Supl. (Contribuições do Projecto Flora Amazônica 7): 195-213.

\section{IDENTIFICATION LIST}

1. F. cotopaxiensis

2. F. ecuadorensis

3. F. francoae

4. F. jacobii

4a. F. jacobii subsp. mantana

5. F. loxensis

6. F. maximoides

7. F. pastasana
8. F. popenoei

8a. F. popenoei subsp. popenoei

8b. F. popenoei subsp. malacocarpa

9. F. quichuana

10. F. quistocochensis

11. F. rimacana

12. F. sumacoana

13. F. valaria

Aguinda et al. 283: 9; 3704: 2 - Aulestia (et al.) 307: 9; 537: 13; 3590: 9 - Ayala 2056: 10; 2057: 10.

Balslev et al. 2975: 9 - Berg (et al.) 1039: 9; 1207: 2; 1275: 1; 1779: 9.

Cabrera et al. 649: 4a - Callejas et al. 3449: 3 - Campos et al. 3183: 6; 5435: 5 - Cerón (et al.) 318: 9; 11852: 5; 22417: 4a; 23844: 5; 29369: 1; 41150: 2; 56828: 2 - Christ 49: 8b - Clark et al. 5096: 2 - Cogollo 1998: 3 - Cornejo et al. 3013: 4a; 3618: 1; 4069: 4a; 5023: 4a; 6963: 4a; 7245: 4a; 7800: 4a - Croat 21025: 6 - Cuascota et al. 118: 4a - Cuatrecasas 8997: 9.

Daly et al. 10906: 6 - Davidse et al. 27294: 8b - Dik 396: 2; 756: 7 — Dodson 7405: 1; 17576: 1.

Emperaire 1336: 5 - Estrada et al. 309: 13.

Foster et al. 6341: 7; 10029: 6 - Franco \& Berg 4588: 3 - Freire et al. 5143: 9; 5311: 2.

Gentry 25514: 6; 43669: 7; 57575: 13 - Graham et al. 319: 6 - Gudiño et al. 1634: 9.

Hammel et al. 16533: 3 - Harling et al. 17703: 9 - Holm-Nielsen et al. 26317: 5 - Hurtado (et al.) 1094: 12; 2893: 9 - Hutchinson \& Wright 6708: 4.

J. Jaramillo et al. 12251: 5; 12308: 5 - N. Jaramillo 1384: 6 - Josse 655: 4a. 
Kayap 122: 6 - Killip et al. 27846: 9 - Kvitvik 2491: 1; 2497: 1; 2942: 1; 2946: 1; 29415: 1; 29459: 2; 29471: 1.

Langendoen et al. 938: 13. - Lehmann 5805: 8a - Lozano et al. 904: 4a.

Miranda et al. 41: 4a - Monsalve B. 1227: 13 - Monteagudo et al. 4969: 6.

Neill et al. 10508: 4a; 11870: 4a; 13567: 9 - P. Núñez et al. 12861: 7 - T. Núñez et al. 602: 9.

Palacios 2964: 9; 3466: 9; 4746: 12; 5334: 5 - Persaud 100: 8b.

Ramirez et al. 8347: 13 - Reyes et al. 1054: 1. — Rodríguez et al. 1574: 6 - Rojas et al. 1440: 6 - Rubio et al. 616: 13; 1578: 13; 1811: 4a.

Samaniego et al. 33: 4a - Santín et al. 56: 9 - Sanz Bisset et al. 373: 6 - Schunke V. 4146: 6; 8497: 6 - D.N. Smith 5319: 6 - Soukup 6077: 11 - Ståhl et al. 6351: 1 - Standley 52688: 8.

Tipaz 548: 9; 900: 4a; 901: 4a; 2615: 4a - Tirado 999: 2 - Tunqui 764: 6.

Vásquez \& Jaramillo 9458: 10 - Vásquez et al. 1569: 6; 2557: 9; 22638: 6 - Villa et al. 400: 9.

Weigend 5314: 6 - Ll. Williams 6311: 6 - Woytkowski 5309: 6.

Yánez et al. 718: 5 - Young et al. 447: 5; 939: 6; 4069: 5.

Zak (et al.) 4335: 9; 5094: 7; 5331: 1; 5691: 1; 5714: 1. 